\title{
Non-Hawaiian lithostratigraphy of Louisville seamounts and the formation of high-latitude oceanic islands and guyots
}

\author{
David M. Buchs ${ }^{a, *}$, Rebecca Williams $^{b}$, Shin-ichi Sano ${ }^{c}$, V. Paul Wright ${ }^{d}$ \\ a Cardiff University, UK \\ b University of Hull, UK \\ c Fukui Prefectural Dinosaur Museum, Japan \\ d National Museum of Wales, UK
}

This is an author accepted manuscript for an article published in Journal of Volcanology and Geothermal Research, doi: 10.1016/j.jvolgeores.2017.12.019.

\section{ABSTRACT}

Guyots are large seamounts with a flat summit that is generally believed to form due to constructional biogenic and/or erosional processes during the formation of volcanic islands. However, despite their large abundance in the oceans, there are still very few direct constraints on the nature and formation of guyots, in particular those formed at high latitude that lack a thick cap of shallow-marine carbonate rocks. It is largely accepted based on geophysical constraints and surficial observations/sampling that the summit platform of these guyots is shaped by wave abrasion during post-volcanic subsidence of volcanic islands. Here we provide novel constraints on this hypothesis and the summit geology of guyots with a lithostratigraphic analysis of cores from three Louisville seamounts (South Pacific) collected during Expedition 330 of the Integrated Ocean Drilling Program (IODP). Thirteen lithofacies of sedimentary and volcanic deposits are described, which include facies not previously recognized on the top of guyots, and offer a new insight into the formation of high-latitude oceanic islands on a fastmoving plate. Our results reveal that the lithostratigraphy of Louisville seamounts preserves a very consistent record of the formation and drowning of volcanic islands, with from bottom to top: (i) volcaniclastic sequences with abundant lava-fed delta deposits, (ii) submarine to subaerial shield lava flows, (iii) post-volcanic shallow to deeper marine sedimentary rocks lacking thick reef deposits, (iv) post-erosional rejuvenated volcanic rocks, and (v) pelagic sediments. Recognition of erosional boundaries between subaerial lava flows and shallow-marine sedimentary rocks provides novel support for post volcanic wave planation of guyots. However, the summit geology of Louisville seamounts is dissimilar to that of high-latitude Hawaiian-Emperor guyots that have emplaced in a similar tectonic and environmental setting and that include thicker lava stacks with apparently little lava-fed delta deposits. To explain observed lithostratigraphic discrepancy we propose that Louisville seamounts represent a distinct type of intraplate ocean volcano characterized by formation of a smaller island, with a central shield volcano surrounded by extended shallow-marine shelves formed by lava-fed deltas. In this interpretation the summit platform of Louisville-type guyots results from early (syn-volcanic) subaerial to shallow-marine constructional volcanic processes and marine erosion, enhanced by later (post-volcanic) wave planation. This contrasts with larger Hawaiian edifices that are capped by thicker shield volcanoes, and that develop an extended wave planation surface during postvolcanic subsidence (in the absence of efficient coral growth). The difference between Hawaiian- and Louisville-type volcanic islands and guyots can be explained by contrasted dynamic disequilibrium between magmatic growth, erosion, and subsidence during the island-building stage. Unlike Hawaiian- 
type volcanoes, Louisville seamounts are characterized by alkaline magmatism that extends from the late seamount to island stages. This supports more limited magmatic growth during the formation of Louisville islands, and we hypothesize that this promotes the formation of ephemeral shallow-marine platforms and extended lava-fed deltas. Hawaiian-type volcanoes and guyots are unusually large in the population of intraplate ocean volcanoes. Louisville-type guyots as defined in this study could therefore represent a very common but yet poorly documented mode of oceanic island formation in the Pacific Ocean and other similar fast-moving plate settings.

\section{INTRODUCTION}

Millions of seamounts occur in the oceans that range in height from a few tens of meters to several kilometres, come in a very large range of shapes and forms, and preserve a ca. $180 \mathrm{~m}$.yr. history of intraplate ocean volcanism (Schmidt and Schmincke, 2000; Staudigel and Clague, 2010; Buchs et al., 2015; Staudigel and Koppers, 2015). In fastmoving (Pacific-like) plate settings where the lithosphere moves quickly above melting anomalies in the asthenosphere, it is generally accepted that the tallest, island-building intraplate ocean volcanoes grow predominantly through constructional submarine to subaerialshield volcanic phases dominated by tholeiitic magmatism. Shoaling of a seamount and emergence of an island can be marked by a particular phase of phreatomagmatic or "Surtseyan" volcanism. Incipient magmatic waning in the end of the shield-building stage of the island is accompanied by post-shield alkaline volcanism. Finally, fast drifting away from the melting region and rapid magmatic cessation are associated with relatively rapid (few m.yr.) subsidence and drowning of the island, with only minor and sporadic post-erosional, strongly alkaline volcanic activity (e.g., Clague and Dalrymple, 1987; Staudigel and Clague, 2010). On slow-moving (Atlantic-like) plates, oceanic islands develop through broadly similar processes, but slower migration away from the melting region results in longer-lived islands that can form primarily through alkaline magmatism. These volcanoes generally experience limited subsidence, with a prolonged phase of subaerial and shallow-marine erosion accompanied by sporadic volcanic activity (e.g. Staudigel and Schmincke, 1984; Carracedo, 1999; Schmidt and Schmincke, 2002; Ramalho et al., 2013).

The model of formation of Pacific islands, displayed in many geology textbooks, is well supported by studies of large volcanoes at Hawaii and along the Hawaiian-Emperor seamount chain (e.g., Clague and Dalrymple, 1987; Garcia and Davis, 2001; ODP Leg 197 Shipboard Scientific Party, 2002a, 2002b, 2002c, 2002d; Garcia et al., 2007). However, it remains unclear whether these unusually large volcanoes are good analogues of much more abundant, but far less studied, flat topped seamounts or "guyots" that are commonly considered to represent drowned oceanic islands elsewhere in the Pacific (Hess, 1946; Menard, 1984). It is well documented that many guyots in the Pacific are capped by thick shallow-water carbonate deposits that reflect reef growth on top of a subsiding volcanic island/seamount (Darwin, 1842; Winterer et al., 1993; Dickinson, 1998; Wilson et al., 1998; Flood, $1999,2001)$. This biologically-controlled mechanism is particularly effective in lower latitudes where favorable environmental conditions facilitate compensation of subsidence by reef-building organisms and promote formation of long-lived atolls. In contrast, the morphology of high-latitude guyots devoid of a summit shallow-water carbonate platform is generally considered to reflect erosional processes with the formation of a marine planation surface during submergence of extinct volcanic islands (Hess, 1946). Alternatively, the summit platform of these seamounts could be due to constructional volcanic processes with limited control by erosional mechanisms (Nayudu, 1962; Christensen and Gilbert, 1964; Simkin, 1972; Natland, 1976). The constructional hypothesis has however received relatively little attention in the literature probably due to lack of clear supporting observations from guyots. Yet, it is significant to note that robust evidence for the more widely acknowledged existence of a wave planation surface on top of guyots remains equally elusive. The main direct support for this hypothesis is based on the occurrence of well-rounded clasts on top of these seamounts (e.g., Carsola and Dietz, 


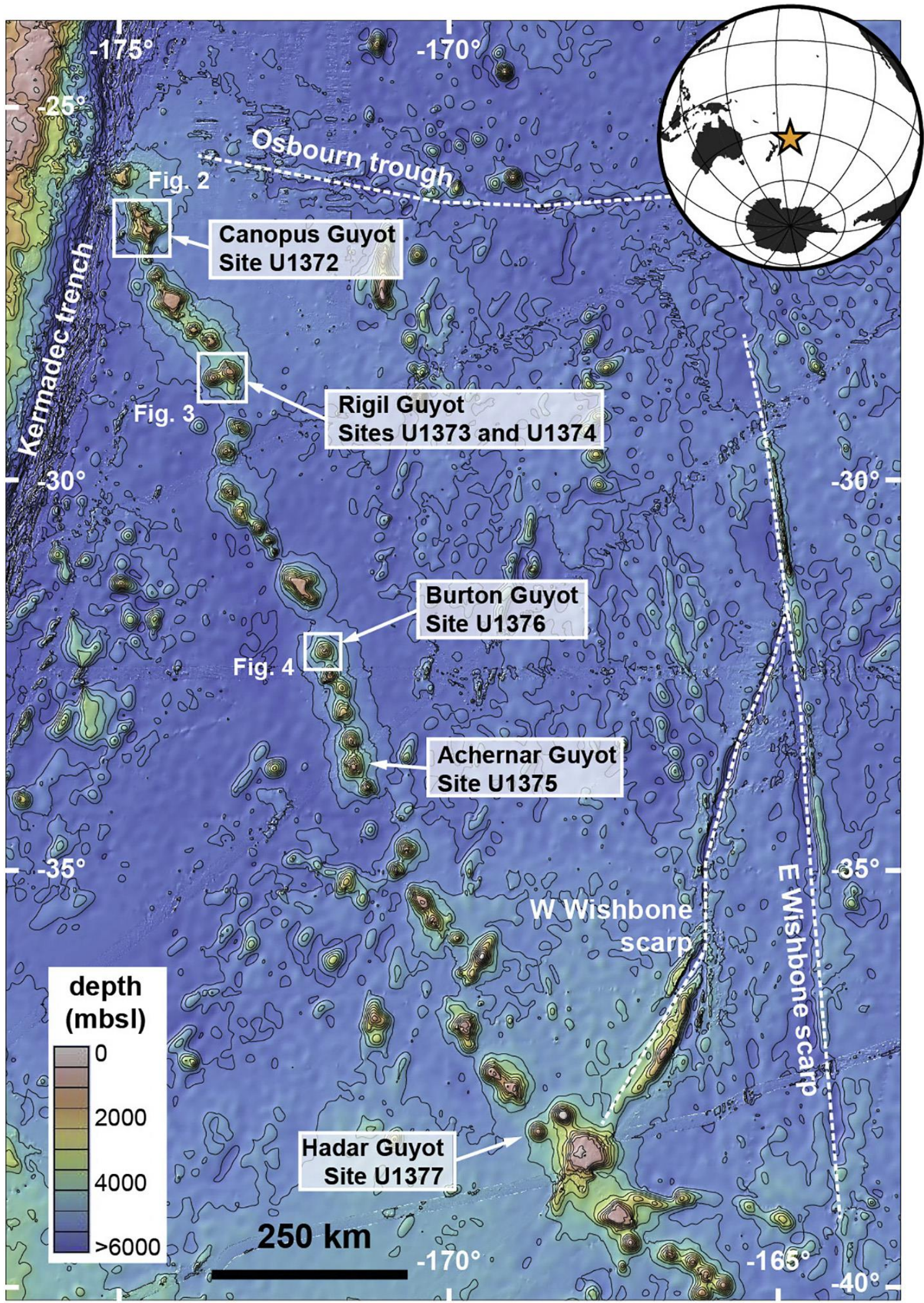

Fig 1. Map of the northwestern end of the Louisville seamount chain showing the location of the guyots drilled during IODP expedition 330. Contours are every 500m.Map constructed using GeoMapApp (http://www.geomapapp.org, v. 3.5.1, retrieved on 2 July 2015) and the Global Multi-Resolution Topography (GMRT) synthesis (Ryan et al., 2009). 
1952; Hamilton, 1956; Budinger, 1967; Paduan et al., 2009), but these deposits are not incompatible with the possibility of the morphology of the guyots being controlled at least in part by earlier volcanic constructional processes.

We provide here new direct constraints on the nature of the summit geology of three guyots of the Louisville seamount chain drilled to a depth of 183 to $522 \mathrm{~m}$ below sea floor (mbsf) during IODP Expedition 330 (Fig. 1). High (60-88\%) recovery of drilled sequences offers a unique insight into geological processes that took place shortly before, during and after the island building stage of these volcanoes. We characterize these processes based on a sedimentary and volcanological lithostratigraphic analysis, including description of facies recognized for the first time on top of seamounts. The studied lithostratigraphic record offers a unique opportunity to test existing models of formation of high-latitude guyots in the Pacific. We show that our lithostratigraphic results and a large range of novel constraints from Louisville are partly at odds with the traditional model of formation of Hawaiian intraplate ocean volcanoes. We propose that this issue can be resolved by the introduction of a new model of formation of guyots applicable to Louisville-type volcanoes, in which the summit platform results from a complex interplay of constructional and erosional processes during formation of a small island in a fast-moving plate setting.

\section{GEOLOGICAL BACKGROUND}

The Louisville seamount chain is a $4300 \mathrm{~km}$-long Late Cretaceous to Cenozoic chain of large, predominantly flat-topped intraplate ocean volcanoes that extends from the Kermadec trench to approximately $145^{\circ} \mathrm{W}$ in the South Pacific (Lonsdale, 1988). Age progression along the chain supports a hotspot origin with volcanoes progressively younger towards the east (Koppers et al., 2011). Apparent absence of an active hotspot at the eastern end of the chain suggests that most Louisville seamounts were produced during waning of a now extinct Louisville hotspot (Lonsdale, 1988). Basalts recovered by dredging and drilling on the seamounts have only yielded alkaline and transitional geochemical affinities, with so far no evidence for tholeiitic magmatism (Hawkins et al., 1987; Beier et al., 2011; Koppers et al., 2012a; Nichols et al., 2014; Vanderkluysen et al., 2014; Dorais, 2015). Drill cores considered in this study were collected during IODP Expedition 330 at the top of 3 guyots along the older (80-50 Ma) segment of the Louisville seamount chain (Koppers et al., 2012a) (Fig. 1). All seamounts formed on a Cretaceous oceanic plate between the Osbourne Trough that represents an extinct mid-ocean ridge (Worthington et al., 2006; Downey et al., 2007), and the west branch of the Wishbone Scarp that is considered to represent an inactive transform fault (Lyons et al., 2000; Mortimer et al., 2006). Guyots along the western segment of the Louisville seamount chain formed at high latitude ca. $51^{\circ} \mathrm{S}$ (Koppers et al., 2012b). With the exception of Guyot $168^{\circ} \mathrm{W}$ along the W Wishbone Scarp, there is no evidence for the development of thick shallow-marine carbonate deposits on the seamounts (Lonsdale, 1988; Ebuna, 2011; Koppers et al., 2012a; Vanderkluysen, pers. com. 2015). The core of Louisville seamounts is considered to be composed of igneous intrusions (Contreras-Reyes et al., 2010), but the exact origin of their summit platform has remained difficult to constrain in the absence of direct subsurface observation.

\section{METHODS}

New lithological and stratigraphic observations were conducted using core and thin section observations from four drill sites on Canopus, Rigil and Burton guyots, for a total sequence thickness of $1003 \mathrm{~m}$ (Figs. 2-4). Cores considered in this study were collected at Site U1372 on Canopus Guyot (233 m-long, 60\% recovery), Sites U1373 and 1374 on Rigil Guyot (66 and 522 m-long, 72\% and 88\% recovery, respectively), and Site U1376 on Burton Guyot (183 m-long, 75\% recovery) (Koppers et al., 2012a). In previous studies Canopus, Rigil and Burton guyots are sometimes described as seamounts 

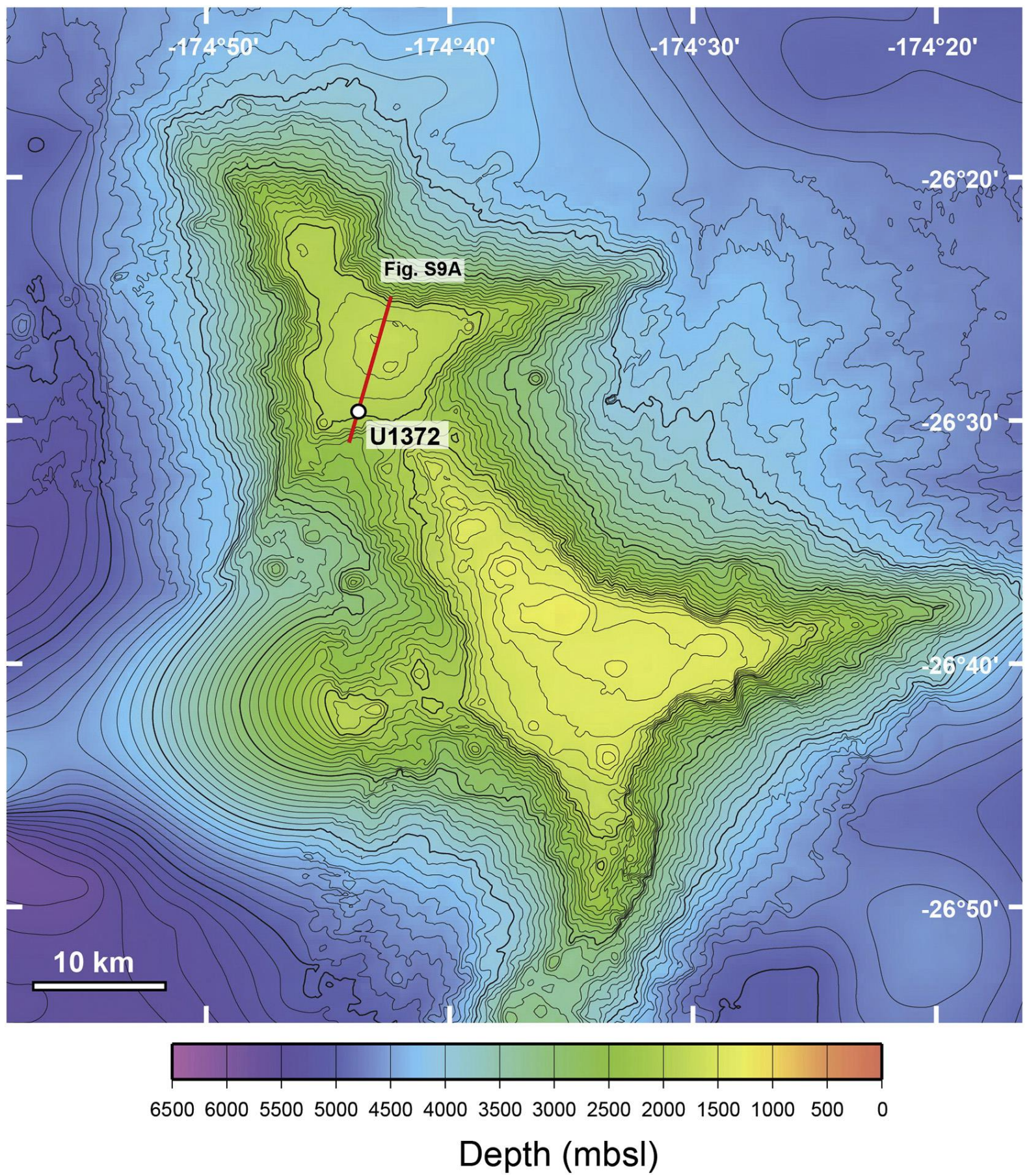

Fig 2. Bathymetric map of Canopus Guyot $\left(26.5^{\circ} \mathrm{S}\right.$ Guyot) with location of IODP Site U1372, and seismic profile in red (modified from Koppers et al., 2010). (For interpretation of the references to color in this figure legend, the reader is referred to the web version of this article.)

$26.5^{\circ} \mathrm{S}, 28.6^{\circ} \mathrm{S}$, and $32.3^{\circ} \mathrm{S}$, respectively. Core images were collected during IODP Expedition 330 onboard R/V JOIDES Resolution using a line scan camera (Section Core Imaging Logger, SHIL) at intervals of 20 pixels/mmon archive half-core sections (Koppers et al., 2012a, all materials available through the IODP online portal). Minor tonal adjustments of original color were made to improve readability of lithological characteristics in poorly contrasted (e.g., dark colored) units. Lithologies were characterized based on the composition and fabric of volcanogenic and sedimentary rocks/deposits. Clast sorting and clast roundness subdivisions are from Jerram (2001) and Powers (1953), respectively. When volcaniclastic deposits have an unambiguous primary origin the nomenclature of White and Houghton (2006) was used. The classification of limestones is based on Dunham (1962), as revised by 

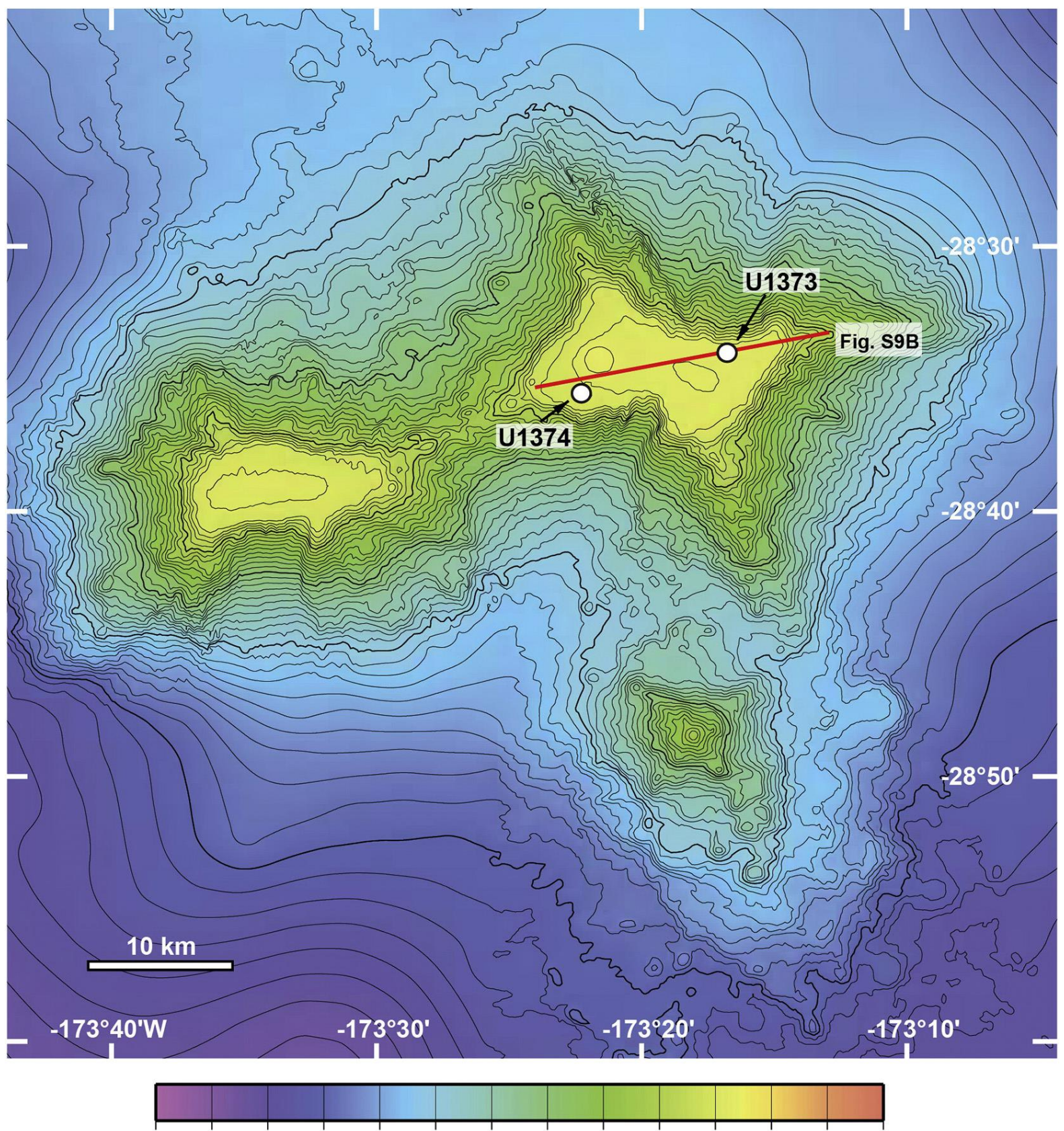

$650060005500500045004000350030002500200015001000500 \quad 0$

Fig 3. Bathymetric map of Rigil Guyot (28.6 ${ }^{\circ} \mathrm{S}$ Guyot) with location of IODP Sites U1373 and U1374, and seismic profile in red (modified from Koppers et al., 2010). (For interpretation of the references to color in this figure legend, the reader is referred to the web version of this article.)

Embry and Klovan (1972). The modal abundance of fossils was determined using visual charts by Baccelle and Bosellini (1965). Qualitative characterization of the lithostratigraphic development of the guyots was conducted based on a unified catalogue of lithofacies developed from new core and thin section observations, which we applied to the stratigraphic subdivision developed on-board during IODP Expedition 330 (Koppers et al., 2012a). Due to large lithological variations observed at the studied seamounts this approach allowed us to reconstruct the lithostratigraphic evolution with a high degree of consistency across the drill sites. Process and palaeo-environmental interpretations of lithofacies integrate sedimentological, volcanological and palaeontological constraints from terrestrial to coastal and marine settings. Lithostratigraphic analysis from the four drill sites focused on the transition from syn-volcanic to post-volcanic processes. Given the scope of this study our approach 

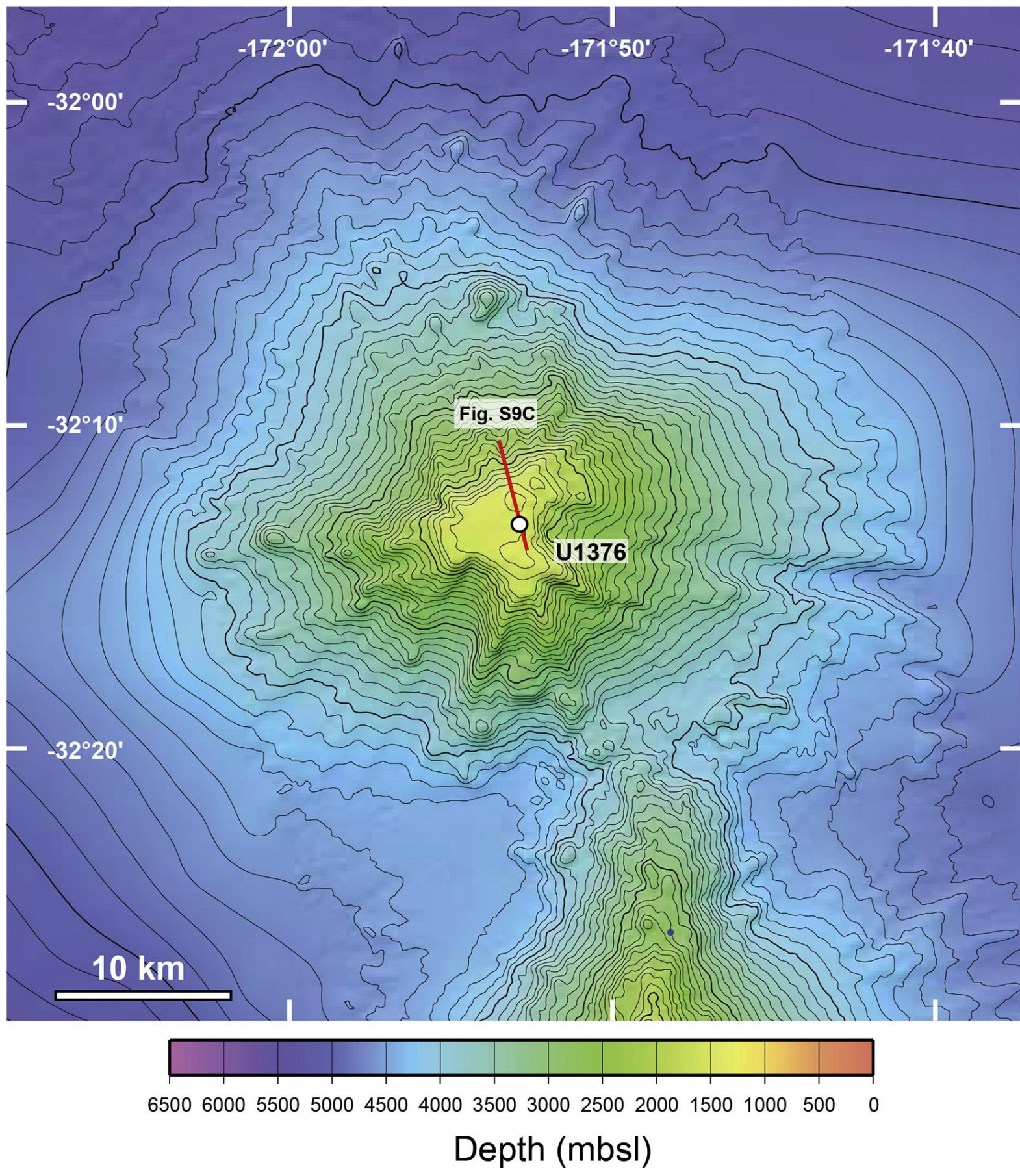

Fig 4. Bathymetric map of Burton Guyot (32.3 ${ }^{\circ} \mathrm{S}$ Guyot) with location of IODP Site U1376, and seismic profile in red (modified from Koppers et al., 2010). (For interpretation of the references to color in this figure legend, the reader is referred to the web version of this article.)

does not intend to resolve in detail the volcanological complexity expected to occur in the basement of the seamounts.

\section{LITHOFACIES DEFINITION AND PALAEO-ENVIRONMENTAL CONSTRAINTS}

Preliminary results from IODP Expedition 330 show that the upper part of Louisville guyots are composed of abundant primary and reworked volcanic breccias, with subordinate basaltic lava flows and intrusive igneous rocks, and rare non-volcanic sedimentary deposits (Koppers et al., 2012a). These lithologies are subdivided here into pelagic and hemipelagic sedimentary deposits, shallow-marine 
Table 1. Characteristics of the 13 lithofacies recognized on Louisville Guyots

\begin{tabular}{|c|c|c|c|c|c|c|c|c|c|c|}
\hline Lithofacies &  & 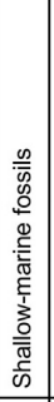 & 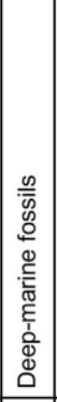 &  & 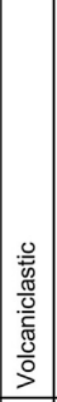 & 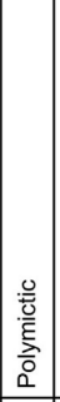 & 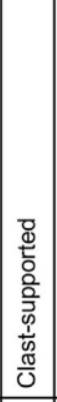 & 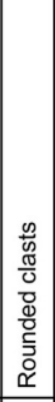 & \begin{tabular}{|c|}
$\frac{n}{0}$ \\
$\frac{0}{0}$ \\
0 \\
0 \\
0 \\
0 \\
0 \\
0 \\
\end{tabular} & Interpretation \\
\hline \begin{tabular}{|l|}
$\begin{array}{l}\text { Lithofacies } 1 \\
\text { (ferromanganese crust/nodule) }\end{array}$ \\
\end{tabular} & $\bullet$ & & & & & & & & & Pelagic (chemical) sedimentation \\
\hline $\begin{array}{l}\text { Lithofacies } 2 \\
\text { (winnowed foraminiferal sand) }\end{array}$ & $\bullet$ & & $\bullet$ & & $\circ$ & & & & & Pelagic sedimentation affected by currents and winnowing \\
\hline \begin{tabular}{|l|} 
Lithofacies 3 \\
(hemipelagic/pelagic limestone)
\end{tabular} & $\bullet$ & $\circ$ & $\bullet$ & $\bullet$ & $\bullet$ & $\bullet$ & & & & Pelagic sedimentation without (or with limited) winnowing \\
\hline \begin{tabular}{|l} 
Lithofacies 4 \\
(algal boundstone to rudstone)
\end{tabular} & $\bullet$ & $\bullet$ & & - & $\bullet$ & $\bullet$ & & & & Shallow-marine sedimentation on a drowning island \\
\hline \begin{tabular}{|l} 
Lithofacies 5 \\
(breccia with infill fabric)
\end{tabular} & & $\circ$ & $\circ$ & - & $\bullet$ & $\bullet$ & $\bullet$ & $\circ$ & & $\begin{array}{l}\text { Talus deposit, submerged wave-cut platforms facing cliffs of } \\
\text { a drowning island. }\end{array}$ \\
\hline \begin{tabular}{|l} 
Lithofacies 6 \\
(clast-supported conglomerate)
\end{tabular} & & $\bullet$ & & - & $\bullet$ & $\bullet$ & $\bullet$ & $\bullet$ & & Beachrock and/or near-shore sedimentation. \\
\hline $\begin{array}{l}\text { Lithofacies } 7 \\
\text { (matrix-supported breccia) }\end{array}$ & & $\circ$ & & & $\bullet$ & $\bullet$ & & $\circ$ & $\circ$ & Debris-flow deposit, possibly lahar. \\
\hline $\begin{array}{l}\text { Lithofacies } 8 \\
\text { (juvenile volcanic breccias) }\end{array}$ & & & & & $\bullet$ & & $\bullet$ & & - & $\begin{array}{l}\text { Hyaloclastite, pillow breccia, and glass-poor basaltic } \\
\text { breccias emplaced in lava-fed deltas and/or clastic aprons. }\end{array}$ \\
\hline $\begin{array}{l}\text { Lithofacies } 9 \\
\text { (gradded/laminated breccia and tuff) }\end{array}$ & & & & & $\bullet$ & $\circ$ & $\bullet$ & & - & $\begin{array}{l}\text { Volcanically-induced density current deposit and pyroclastic } \\
\text { deposit. }\end{array}$ \\
\hline $\begin{array}{l}\text { Lithofacies } 10 \\
\text { (lobate, massive and brecciated lava) }\end{array}$ & & & & & & & & & & Lava flow (submarine or subaerial). \\
\hline $\begin{array}{l}\text { Lithofacies } 11 \\
\text { (pillow lava) }\end{array}$ & & & & & & & & & & Lava flow (submarine). \\
\hline $\begin{array}{l}\text { Lithofacies } 12 \\
\text { (peperite) }\end{array}$ & & & & $\bullet$ & - & & & & $\bullet$ & $\begin{array}{l}\text { Mingling of sediment and lava flow with local fragmentation } \\
\text { of the lava. }\end{array}$ \\
\hline $\begin{array}{l}\text { Lithofacies } 13 \\
\text { (intrusive sheet) }\end{array}$ & & & & & & & & & & Intrusive igneous rocks. \\
\hline
\end{tabular}

$\bullet=$ common, $\mathrm{o}=$ rare, $\boldsymbol{Q}=$ = variable (absent to common), blank = absent or exceptional

carbonate rocks, volcaniclastic deposits, and effusive and intrusive igneous rocks. These groups are subsequently subdivided into thirteen lithofacies to characterize volcano-sedimentary processes and palaeo-environmental conditions during the formation of the studied guyots (Table 1).

\subsection{Pelagic and hemipelagic sedimentary deposits}

Pelagic and hemipelagic sedimentary deposits can be subdivided into 3 lithofacies.

Lithofacies 1 consists of black ferromanganese crusts and nodules that occur exclusively in the uppermost parts of the studied guyots, with a variable thickness of 1 to approximately $30 \mathrm{~mm}$. Rarely, the crusts are associated with phosphatized limestone of lithofacies 3 (Fig. 5B). Although phosphatization can be significant on top of seamounts (Cullen and Burnett, 1986; Hein et al., 1993; Benninger and Hein, 2000; Jones et al., 2002), little phosphorite has been encountered on top of the studied guyots (Koppers et al., 2012a). Ferromanganese crusts are ubiquitous in the ocean (Hein and Koschinsky, 2014); on top of seamounts swept by oceanic currents their formation is very slow, with rates of approximately 1 to 5 mm/Ma (e.g., Puteanus and Halbach, 1988; Abouchami et al., 1997; Ling et al., 1997). Ferromanganese crusts on Louisville seamounts can therefore be used to recognize prolonged sedimentary and volcanic quiescence during the formation of the guyots.

Lithofacies $\mathbf{2}$ is composed of loose planktic foraminiferal ooze/sand trapped in cavities or topographic lows on top of the guyots (Fig. 5A, Fig. S1). Sedimentary structures of this facies were not preserved 

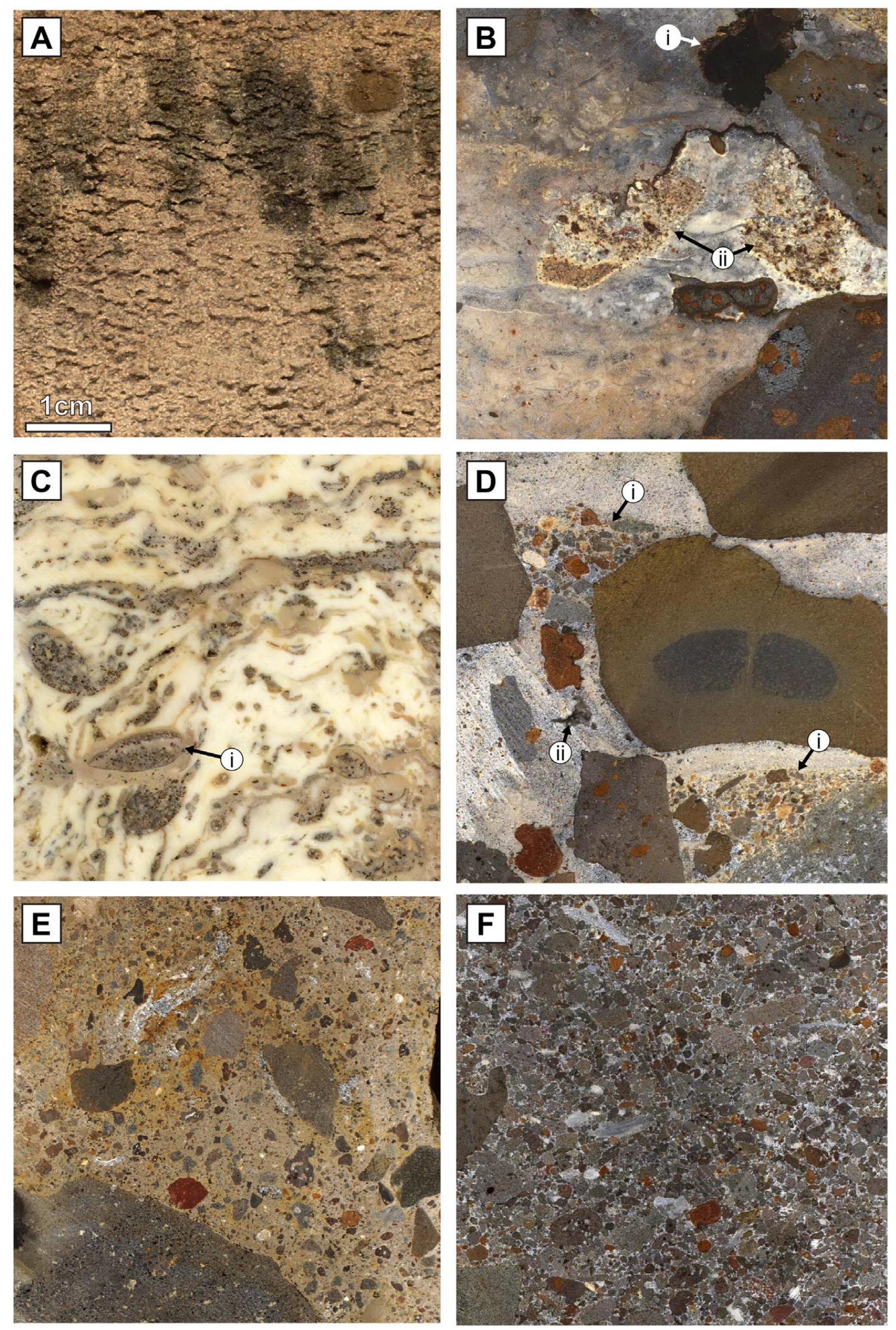
Fig 5. Synthetic illustration of sedimentary lithofacies drilled in Louisville seamounts (imagewidth=5 $\mathrm{cm}$ ). (A) Lithofacies 2, winnowed foraminiferal sand (interval 330-U1372A-3R-2-A, 52-57 cm on Canopus Guyot). This facies corresponds to the youngest (loose) sediment capping Louisville guyots, which is interpreted as sand waves formed under the influence of deep sea currents. The foraminiferal sand locally includes darker material composed of drift pumices and fallout tuff. (B) Lithofacies 3, hemipelagic/pelagic limestone (interval 330-U1374A-3R-1-A, 67-72 cm on Rigil Guyot). Here includes a ferromanganese nodule of lithofacies 1 (i) and possible burrows filled by tuff of lithofacies 9 (ii). (C) Lithofacies 4 , coralline algal boundstone to rudstone (interval 330-U1376A-4R-3-A, 112-117 cm).). This facies is restricted to an algal framework found at the summit of Burton Guyot. Illustrated example is composed of encrusting forms of coralline algae with boring by bivalves filled by basaltic sandstone and micrite that locally form geopetal structures (i). (D) Lithofacies 5 , breccia with infill fabric, interpreted as a talus deposit on top of Canopus Guyot (interval 330-U1372A-5R-3-A, 68-73 cm). This facies includes secondary finer-grained and micrite deposits ("infills") that form geopetal structures (i), and residual porosity (ii) between the largest clasts. (E) Lithofacies 7, matrix-supported breccia interpreted as debris flow deposit or lahar (interval 330-U1373A-1R-2-A, 47-52 cm on Rigil Guyot). (F) Lithofacies 6, clast-supported conglomerate (interval 330-U1372A-6R3-A, 56-61 cm on Canopus Guyot). This facies includes abundant shallow-marine fossils and well-rounded clasts. It is interpreted as beachrock/coastal deposit.

during core retrieval, but the sorting and lack of abundant finer fraction suggests pelagic deposition under winnowing conditions, as commonly observed on other seamounts of the Pacific (Lonsdale et al., 1972; Lonsdale and Malfait, 1974). Aminor fraction (b5\%) of the sediment is composed of volcanic fragments (sand-sized feldspars, pyroxenes, opaques, glass, and basaltic grains) probably reworked from underlying seamount deposits. Rare pumices found in the foraminiferal sand probably record pumice rafts that have drifted on top of the seamounts from nearby supra-subduction zone volcanoes (e.g., Jutzeler et al., 2014).

Lithofacies 3 consists of fossiliferous to packed wacke/packstone with minor (b10\%) basaltic fragments and generally abundant planktonic and benthic foraminifers (Figs. 5B, 6A). Minor bioclasts include inoceramid and unidentified molluscan shell fragments and echinoderm fragments. This facies is interpreted to have deposited in hemipelagic to pelagic environments during periods of low current activity.

\subsection{Shallow-marine carbonate rocks}

Lithofacies 4 is a coralline algal boundstone to rudstone (Fig. 5C, Fig. S2). This limestone represents a biogenic framework (not forming rhodoliths) related to in situ growth of coralline red algae. It includes encrusting and branching forms of coralline algae,minor bryozoans, annelids, bivalves, echinoderms and solitary corals, with frequent borings by bivalves, dissolution features (cavities) and intraskeletal spaces in the algal framework which are filled with fossil-bearing micrite and/or volcaniclastic material. It is also characterized by the absence of rudists, colonial corals and larger foraminifers, which are typical for the low-latitude reefal environments. Mainly sand- to pebble-sized basaltic grains occur in the lower part of the limestone. This lithologyis indicative of a shallow-marine environment and represents an unusual record of high-latitude algal framework on the studied seamounts. Possible analogues are rare and could include, e.g., the Upper Limestone Member of the Sepultura Formation, Baja California, Mexico (Abbott et al., 1993).

\subsection{Volcaniclastic deposits}

Volcaniclastic deposits form most of the units in the upper part of the Louisville seamounts. We have subdivided them into 5 lithofacies.

Lithofacies $\mathbf{5}$ is composed of a poorly sorted, polymictic breccia with grains ranging in size from sand to cobble and, more rarely, boulder (Fig. 5D, Fig. S3). Clasts are generally very angular to sub-rounded, with occasional rounded to well-rounded grains. The breccia is grain-supported with frequent point contacts between the clasts. The matrix is composed of wacke/packstone (similar to lithofacies 3 ) or sandstone. Carbonate cements and residual porosity are also recognized. The composition of the clasts is essentially basaltic with rare occurrences of reworked shallow-marine bioclasts (e.g., coralline 

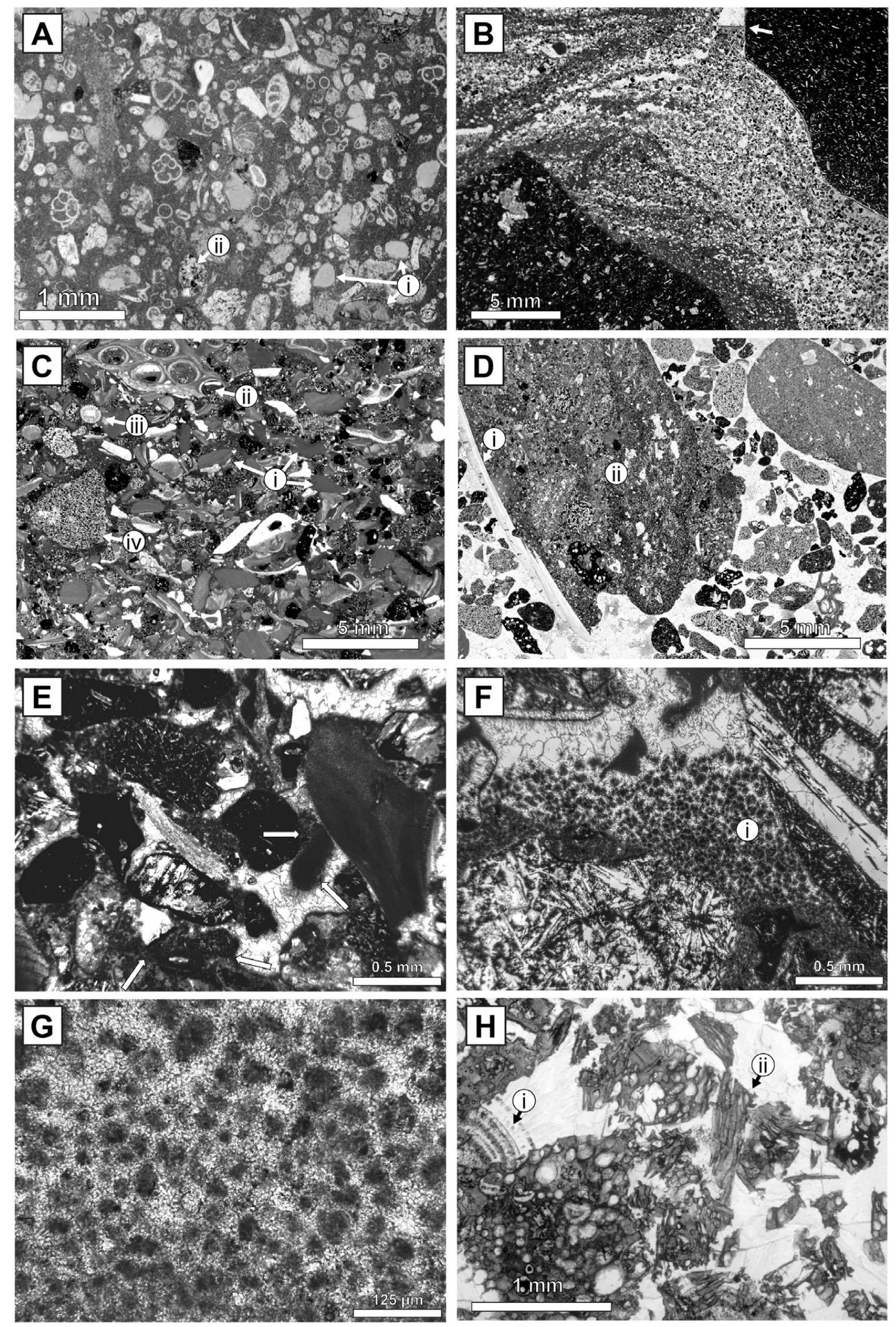
Fig 6. Thin section photographs of selected lithological features. (A) Foraminiferal wacke/packstone (lithofacies 3, pelagic/hemipelagic limestone, core section 330-U1372A-5R-1-W on Canopus Guyot). Contains abundant planktonic and benthic foraminifers (some broken) with minor rounded altered glass (i) and basalt clasts (ii). (B). Breccia with infill and current structures (lithofacies 5, core section 330-U1372A-5R-3-W on Canopus Guyot). Darker matrix is composed of wacke/packstone similar to $(A)$, whereas white areas are composed of carbonate cements. The arrow outlines a geopetal structure formed by infill of wacke/packstone in a late stage fracture/void. (C) Beachrock/coastal deposit (lithofacies 6, core section 330-U1372A-8R-1-W on Canopus Guyot). The sample includes abundant well rounded fragments of red algae (i), and minor fragments of annelid tubes (ii), echinoderm spines (iii), basaltic rocks (iv) and minerals. (D) Beachrock/coastal deposit (lithofacies 6, core section 330-U1372A-7R-2-W on Canopus Guyot). Matrix is mostly composed of carbonate cements except where a large shell fragment (i) allowed preservation of wacke/packstone part (ii) from winnowing. (E) Beachrock/coastal deposit (lithofacies 6, core section 330-U1376A-5R-1-W on Burton Guyot), including micropeloidal cement (highlighted by arrows). (F) Beachrock/coastal deposit (lithofacies 6, core section 330-U1376A-5R1-W on Burton Guyot), including micropeloidal cement infill (i). (G) Micropeloidal cement in beachrock/coastal deposit (lithofacies 6, core section 330-U1376A-5R-1-W on Burton Guyot) (H) Vitric tuff (lithofacies 9, core section 330-U1374A2R-2-W on Rigil Guyot), including spheroidal cement (i) and vitric clasts with elongated vesicles (ii).

red algae). Bottom currents at the time of sedimentation are recorded by cross-lamination. Calcite cementation is observed where fine particles were washed out from the sandstone between the larger clasts (Fig. 6B). A significant feature of this facies is the occurrence of an infill fabric produced by the percolation of finer (generally sandy)material between the larger clasts that form the framework of the breccia (Fig. S3). This clearly indicates that the facies formed incrementally, with large variation in the energy of transport of discrete sedimentation events. Analogy of this fabric with that of subaerial talus or screes (Tanner and Hubert, 1991; Salt and Ballantyne, 1997; Hinchliffe et al., 1998) suggest that lithofacies 5 represents submarine deposits avalanching down from a nearby cliff or escarpment, or submarine deposits reworked downslope during storms. Such deposits are rare on Louisville seamounts and to our knowledge have not been described yet at other seamounts.

Lithofacies 6 consists of a poorly towell sorted, polymictic conglomerate with grains ranging in size from sand to cobble and, more rarely, boulder (Fig. 5F, Fig. S4). Clasts are sub-rounded to wellrounded indistinctively of their size. The conglomerate is grain-supported but locally includes significantly larger clasts in a well sorted matrix. Crossbedding locally occurs in the sandier units. Interstitial space between the clasts includes primary porosity, carbonate cements and/or micrite (Fig. $6 C-D$ ). The conglomerate is dominated by basaltic fragments but locally contains abundant ( 5 to $40 \%$ ) shallow-marine bioclasts, including annelids, coralline red algae, echinoderms, bryozoans and mollusks. Annelids and algae often developed in situ encrustations on the basalt cobbles and boulders. Although significant recrystallization of carbonate cements occurred during late diagenesis, micropeloidal cements with micritic menisci have been observed in Site U1376 on Burton Guyot (Fig. $6 \mathrm{E}-\mathrm{G}$ ). These cements are generally considered as an indicator of microbial activity (Sun and Wright, 1989; Folk and Leo Lynch, 2001; Hillgärtner et al., 2001). Similar peloidal cements, generally identified as microbial in origin, have been described from reefal and slope deposits. For example Heindel et al. (2012) note that thick peloidal cements associated with coralgal frameworks from Tahiti developed in the shallow euphotic zone, 1.5 to $6 \mathrm{~m}$ below the living reef top, but can also develop as depths exceeding $20 \mathrm{~m}$ and as much as $200 \mathrm{~m}$ on slopes (Seard et al., 2011). The presence of non-isopachous cement geometries such as menisci might suggest vadose conditions such as beachrock formation, but similar textures associated with microbial cements have been described from shallow-marine hardgrounds (e.g., Hillgärtner et al., 2001). However, the association with well-rounded clasts and stratigraphic occurrence under coralline framework at Site U1376 (see below) suggest a more likely shallow-water setting. Altogether, preceding characteristics are typical of beachrock/coastal deposit emplaced on oceanic islands and more generally along rocky shore environments (Felton, 2002). We consider therefore that lithofacies 6 records deposition in shallow-marine to possibly intertidal environments along a palaeo-coastline. 


Fig 7. Synthetic illustration of primary volcanic lithofacies drilled in Louisville seamounts (imagewidth=5 $\mathrm{cm}$ ). (A) Lithofacies 8a, primary volcanic breccia (interval 330-U1372A-27R-1-A, 75-80 cm on Canopus Guyot). Selected interval shows a hyaloclastite with highly vesicular clasts. (B) Lithofacies $8 \mathrm{~b}$, primary volcanic breccia (interval 330-U1374A-64R-3A, 100-105 cm on Rigil Guyot), interpreted as a pillow breccia with cement (i) or hyaloclastite matrix (ii). (C) Lithofacies 8b, primary volcanic breccia (interval 330-U1374A-35R-2-A, 39-44 cm on Rigil Guyot), with chilled clasts and pervasive oxidation. (D) Lithofacies 9, laminated breccia (interval 330-U1374A-7R-5-A, 9-14 cm on Rigil Guyot), interpreted as a pillow breccia with a hyaloclastite matrix. (E) Lithofacies 10, Blocky lava flow (interval 330-U1373A-2R-3-A, 82-87 cm on Rigil Guyot). (F) Lithofacies 12, Peperite (interval 330-U1372A-9R-3-A, 59-64 cm on Canopus Guyot).

Lithofacies $\mathbf{7}$ is composed of a poorly sorted, polymictic breccia with grains ranging in size from sand to cobble and, more rarely, boulder (Fig. 5E, Fig. S5). Clasts are very angular to sub-angular (rarely rounded) and composed of basalt fragments. The breccia is matrix-supported with a matrix composed of variously-altered black to yellowish-brownish tuffaceous material, which does not react with $\mathrm{HCl}$. Some of the breccia includes minor (b5\%) shallow-marine bioclasts similar to those found in lithofacies 6. Dispersion of large clasts in the matrix of lithofacies 7 indicates transport in a cohesive tuffaceous medium interpreted to be associated with debris flow, either torrential breccia or lahar (Walton and Palmer, 1988; Smith and Lowe, 1991; Hildenbrand et al., 2008). The absence of cataclastic fragmentation in this facies rules out emplacement as debris avalanches (Ui, 1983; Siebert, 1984). The grain size, matrix-supported fabric and strongly polymictic nature of the breccia are inconsistent with a Surtseyan deposit (e.g., Kokelaar, 1986; Thordarson, 2000; Jakobsson et al., 2009; Schipper andWhite, 2016).

Lithofacies $\mathbf{8}$ includes poorly sorted to moderately sorted, predominantly monomictic breccias with grains ranging in size from ash to lapilli and more rarely, blocks (Fig. 7A-C, Figs. S6, S7). This lithofacies corresponds to primary volcanic breccias that can be subdivided into two sub-facies based on their relative abundance of glass fragments. Lithofacies $\mathbf{8 a}$ is a hyaloclastite predominantly composed of moderately sorted, vesicular glass fragments that can include larger vesicular basalt clasts with a chilled margin and broken or amoeboid textures (Fig. 7A, Fig. S6A-C). This facies is clearly indicative of submarine volcanic activity (Staudigel and Schmincke, 1984; Yamagishi, 1991; White and Houghton, 2006). The clasts generally lack fluidal texture, and are poorly vesiculated and not welded (Fig. S6C shows a rare occurrence of fluidal/lobate juvenile clasts). These characteristics indicate they do not represent spatter deposits formed by submarine fountaining (Simpson and McPhie, 2001; Cas et al., 2003) or magmatic fragmentation during submarine strombolian volcanism (Clague et al., 2009; Deardorff et al., 2011). Significantly, the absence of fine tuff, accretionary lapilli, composite bombs/lapilli lag deposits and winnowing structures indicates that lithofacies 8a did not form as a direct result of Surtseyan volcanism (e.g., Kokelaar, 1986; Thordarson, 2000; Jakobsson et al., 2009; Schipper and White, 2016). Instead, the large abundance of vesicular glass, which locally includes exfoliated margins of lava lobes/pillow lavas (e.g., Fig. 7A) and possible pillow fragments, suggest that thermal shock granulation and spall fragmentation at shallow depth, possibly coupled with impact shattering and "self-peperitization", played a prominent role in the formation of this facies. These observations and stratigraphic relationships (see Section 5 below) suggest that lithofacies 8a deposits emplaced in a shallow-marine clastic apron with locally lava-fed deltas (e.g., Watton et al., 2013).

Lithofacies $\mathbf{8 b}$ is a glass-poor, poorly sorted, grain-supported basaltic breccia (Fig. 7B-C, Figs. S6D,S7A-D). The breccia is generally cemented by carbonates, but can locally preserve original interstitial porosity, and/or includes a basaltic/hyaloclastic coarse ash matrix. The clasts are mostly composed of angular basalt fragments devoid of vesicles and chilled margin, with locally a jigsaw fit texture (Fig. 7B, Figs. S6D, S7B-C). Oxidation of the clasts is locally significant, in particular where the breccia is cemented by carbonate minerals (Fig. 7C, Fig. S7A-C). Lithofacies 8 b locally grades to the brecciated base of lava flows (lithofacies 10 below), which clearly supports a genetic link between the emplacement of the lavas and at least parts of the breccia. Preceding characteristics and stratigraphic relations (see Section 5 below), support formation of lithofacies $8 \mathrm{~b}$ in lava-fed deltas or clastic aprons, 
with fragmentation primarily due to autobrecciation of subaerial lava flows entering the sea (e.g., Watton et al., 2013).

Lithofacies 9 is composed of moderately to well-sorted fine tuff to breccia with a distinctive graded/layered structure (Fig. 7D, Fig. S8). The clasts are very angular to subrounded and composed of fresh to altered volcanic glass and lithics, with a monomictic to polymictic composition. Fragmentation and vesiculation of the clasts can locally be very high, with elongation of some of the vesicles and a fluidal texture (Fig. $6 \mathrm{H}$ ). This suggests syn-eruptive derivation via submarine "fire fountaining" for at least parts of this facies (e.g., Cas et al., 2003; Clague et al., 2009). The breccias are cemented by silicate and carbonate minerals or include a finer grained tuff matrix. This lithofacies is rarely associated with molluscan debris (exceptionally ammonoids), compaction structures in the finer grained deposits, and/or erosional surfaces and cross-bedding. This volumetrically minor facies is believed to have deposited through several processes, including proximal, pyroclastic fall deposits from submarine eruptions (Fig. S8A, D), reworked submarine fall deposits (Fig. S8B), and hyperconcentrated flow deposits (Fig. 7D, Fig. S8C; Smith and Lowe, 1991; Pierson, 2005). Attribution to these processes is discussed below in stratigraphic context.

\subsection{Effusive and intrusive igneous rocks}

All the igneous rocks encountered during the expedition are mafic and they have been subdivided into four lithofacies. The definition of the facies is based on the texture and structure of lava flows/intrusions and does not take into account mineralogical variations. Mineralogy and petrology of individual units is described in Koppers et al. (2012a) and Fitton et al. (submitted).

Lithofacies $\mathbf{1 0}$ is a fine grained, aphyric to highly phyric, variably vesicular, typically massive basalt. Vesicles may occur as subhorizontal bands. This lithofacies can occur as isolated sheets which can grade into brecciated or scoriaceous horizons at either the top or the base of the sheets. This lithofacies is interpreted to represent lava flows with thicknesses that varies between $\sim 0.5$ to over 21 $\mathrm{m}$. The scoriaceous/brecciated deposits (Fig. 7E) are autobrecciated margins typical of lava flows. Where these are red in colour and not in contact with carbonate sediments, this is interpreted to represent subaerial oxidation and emplacement.

Lithofacies $\mathbf{1 1}$ is a fine-grained to glassy variably-brecciated basalt which is typically moderately to highly phyric. The clasts have fine grained cores, glassy chilled margins and are often lobate or curved in morphology. Each lobate body is typically surrounded by thin zones of red clay containing spalled chips of altered glass. This lithofacies is interpreted to represent pillow lavas. Some pipe vesicles in the larger lobate bodies are orientated vertically, and demonstrate that the pillows are typically in situ. Some large (N5 cm) basalt clasts embedded in lithofacies 8a (hyaloclastite) could represent fragments of pillow lava, but grain-supported basaltic breccia convincingly resulting from fragmentation of pillow lavas (e.g., pillow breccias in Staudigel and Schmincke, 1984) have not been observed.

Lithofacies 12 is composed of fine-grained, often highly vesicular basalt and ranges from aphyric to highly-phyric. The basalt is mingled with sediments. The sediments often show squeezing features and compaction swales. In places, the contact is fluidal, sometimes brecciated and occasionally reddened from oxidation. This lithofacies often grades into lithofacies 10 and has been interpreted as peperites (Skilling et al., 2002) (Fig. 7F). This suggests that the lava flows were emplaced over or into wet sediment.

Lithofacies 13 is composed of massive, fine-grained basalt. It is typically aphyric though some discrete patches of phenocrysts can be observed. Vesicles, when present, are aligned in vertical bands. Observed contacts have a cross-cutting relationship and typically dip at $50-60^{\circ}$ but in some places are 
subvertical to vertical. Bands of vesicles are often observed parallel to the margins. In places a chilled margin runs parallel to the edge of the core and may be brecciated. This lithofacies is interpreted as intrusive sheets, most likely dykes, cross-cutting the other units.

\section{LITHOSTRATIGRAPHY OF THE GUYOTS}

This section describes the lithostratigraphic arrangement of the 4 cores collected at the 3 studied Lousiville seamounts. This arrangement is briefly discussed in terms of changes in volcanosedimentary processes and palaeo-environmental conditions during the latest stages of evolution of each of the guyots. The evolution patterns are further discussed and synthesized in the following section, with the introduction of an improved model of formation of guyots.

\subsection{Canopus Guyot (Site U1372)}

Site U1372 is located along the edge of the summit platformof Canopus Guyot (Fig. 2, Fig. S9A). The upper $\sim 13 \mathrm{~m}$ of the cored interval are composed of a shallow-marine to deep-marine sedimentary sequence that rests unconformably on top of a volcanic/volcaniclastic basement that extends down to $232 \mathrm{mbsf}$ (Fig. 8). The volcaniclastic basement is composed of an assemblage of hyaloclastite (lithofacies 8a), lava flows (lithofacies 10), and peperites (lithofacies 12), with a clear increase in the abundance of lava flows up-section. The basement can be subdivided into four sequences of approximately $20 \mathrm{~m}$ thickness composed of hyaloclastites topped by thinner intervals of lava flows. This stratigraphic arrangement and the lithological characteristics of the deposits closely resemble those of lava-fed deltas and clastic aprons formed during the entry of subaerial lava flows into the sea (Moore et al., 1973; Yamagishi, 1991; Schmidt and Schmincke, 2002; Skilling, 2002; Watton et al., 2013). The occurrence of a clastic apron and/or lava deltas in the volcanic basement is additionally supported by low volatile contents in the glass of the hyaloclastites, which indicate degassing in subaerial conditions or at shallow (b20 m) depth (Nichols et al., 2014). The volcanic basement above $\sim 94$ mbsf becomes predominantly composed of massive and brecciated lava flows. Between 90 and $54 \mathrm{mbsf}$ basalts are red oxidized, which suggest emplacement in a subaerial environment (Koppers et al., 2012a). Subaerial lava flows are capped by a peperite unit below the sedimentary cover, which suggests subsidence of the island during the end of the shield building volcanic activity.

The sedimentary cover rests on top of the peperites along an erosional contact (Fig. S10A) that marks a major lithostratigraphic discontinuity from primary volcaniclastic deposits and lava flows to epiclastic volcaniclastic deposits. The lower part of the sedimentary cover includes $\sim 19$ mof nearshore/littoral conglomerate (lithofacies 6 , rich in shallow marine bioclasts) that rests on top of- and fills in cracks in- underlying peperites. The conglomerate is followed up-section by $\sim 9 \mathrm{~m}$ of talus breccias (lithofacies 5, poor in shallow-marine bioclasts), and $\sim 13 \mathrm{~m}$ of recent winnowed foraminiferal sand (lithofacies 2). Lithofacies 5 is interrupted at $\sim 18$ mbsf by a thin bed of foraminiferal wacke/packstone (lithofacies 3 ) capped by a $2 \mathrm{~cm}$-thick ferromanganese crust (lithofacies 1 ). This indicates protracted erosion (probably several m.yr.) after the volcanic/constructional phase of the edifice.

Lithostratigraphic changes at Site U1372 record the formation and drowning of an oceanic island with (1) a constructional volcanic, submarine to shield building phase preserved in the volcanic basement, and (2) an erosional and subsidence phase preserved in the sedimentary cover, following magmatic waning and formation of a major erosional unconformity. Although post-erosional magmatic rejuvenation is not documented in existing cores, it is supported by the occurrence of a cone of possible submarine volcanic origin on top of the guyot (Fig. S9A) (Ebuna, 2011). The life span of the island can be estimated to be b5 m.yr. based on a 74.2 $\pm 0.5 \mathrm{Ma}$ Ar-Ar age from the volcaniclastic basement (Koppers et al., 2012b) and biostratigraphic data from the foraminiferal wacke/packstone in the sedimentary cover (Late Cretaceous, 69-73 Ma, Koppers et al., 2012a). 


\subsection{NE Rigil Guyot (Site U1373)}

Site U1373 is located on the north-eastern edge of the summit platform of Rigil Guyot (Fig. 3, Fig. S9B), where an interval of $\sim 65 \mathrm{~m}$ was cored. This interval includes a $\sim 34 \mathrm{~m}$ thick volcanic basement with lava flows and peperites (lithofacies 10 and 12), and a volcano-sedimentary cover with debris flow deposits (lithofacies 7), bioclast-rich conglomerate with cross-bedded poorly-cemented sandstone (lithofacies 6), and brecciated lava flows (lithofacies 10) (Fig. 9). Lithofacies 6 includes remarkable examples of littoral sediments deposited along a volcanic island (Fig. S4C). Debris flow deposits have a tuffaceous matrix suggesting that they represent lahars (Fig. S5). Occurrence of these deposits and an unusually thick lava flow (Unit VII) indicates possible channelization of flows in/at the mouth of a palaeo-valley. The contact between the volcanic basement and the sedimentary cover was not recovered and, thus, it is unclear whether an erosional unconformity developed before deposition of the sediments. However, the occurrence of shoreline deposits and oxidized basalt clasts in the sedimentary rocks (e.g., Fig. 5 and Fig. S5) supports the existence of a nearby subaerial environment at the time of deposition. Lava interbeds in the sedimentary cover indicate synchronous volcanic and erosional processes, following the development of beaches along an island coast. Similarly to lithostratigraphic constraints at Canopus Guyot this evolution is consistent with subsidence of the island during the end of shield volcanism.

\subsection{SW Rigil Guyot (Site U1374)}

Site U1374 is located along the southwestern edge of the summit platform of Rigil Guyot (Fig. 3, Fig. S9B). The volcanic basement between approximately 523 and 38 mbsf includes abundant primary volcanic breccia (lithofacies $8 \mathrm{a}$ and $8 \mathrm{~b}$ ) with minor igneous dykes and sills (lithofacies 13), and intervals of lava flows (lithofacies 10) and peperites (lithofacies 12) (Fig. 10). The breccia is predominantly composed of lithofacies $8 b$, with coarse hyaloclastite (lithofacies $8 \mathrm{a}$ ) restricted to the lower part of the hole. Lithofacies $8 \mathrm{~b}$ is increasingly oxidized from 340 to $350 \mathrm{mbsf}$ up-section. Prominent oxidation of the breccia broadly corresponds to the apparition up-section (from $290 \mathrm{mbsf}$ ) of thin intervals with shallow-marine bioclasts. This suggests that oxidation could be associated with decarbonation of sediment at the contact with the igneous breccia. In addition to lithological characteristics, several converging observations suggest that lithofacies $8 \mathrm{~b}$ emplaced in lava-fed deltas and/or submarine clastic aprons. First, lava flows are commonly interbedded with compositionally similar, monomictic breccias and locally grade to breccias with a jigsaw-fit texture (Fig. S7B). This is consistent with autobrecciation such as that seen in lava-fed deltas (Watton et al., 2013). Second, the breccias are interbedded with sedimentary intervals that contain shallow-marine fossils and/or conglomerates (see below). This is clear evidence for emplacement of at least parts of the breccias in a shallow-marine environment. Third, bedding in the breccias is rare, but when present indicates N10 $0^{\circ}$ slopes (Fig. S7D) not observed in the lower, hyaloclastite sequence. Finally, the glass in the breccia is degassed, which is consistent with eruption in subaerial and/or shallow-marine environments (Nichols et al., 2014). Another significant observation at Site $\mathrm{U} 1374$ is that lithofacies $8 \mathrm{~b}$ grades in the lower part of the hole to undegassed hyaloclastites that record an eruption depth of 300-550 m (Nichols et al., 2014). Thus, changes in lithofacies 8 distribution of shallow-marine fossils are best accounted for by lava fragmentation in a deep to shallow submarine clastic apron, with the source of the lavas changing from submarine to subaerial with time (i.e., emergence of a volcanic island).

Additional constraints on the palaeoenvironment of the volcanic basement are provided by three main sedimentary intervals. The lowest interval,Unit XI ( 110 to $116 \mathrm{mbsf}$, Fig. 10), is composed of shallowmarine bioclast-bearing conglomerate (lithofacies 6 ) that grades up-section to talus deposits with a bioclast-rich carbonate matrix (lithofacies 5). The abundance of shallow-marine bioclast (including large articulated bivalves in the conglomerate) and the lithological characteristics of the deposits document the development of a littoral environment in the volcanic basement, with possible 


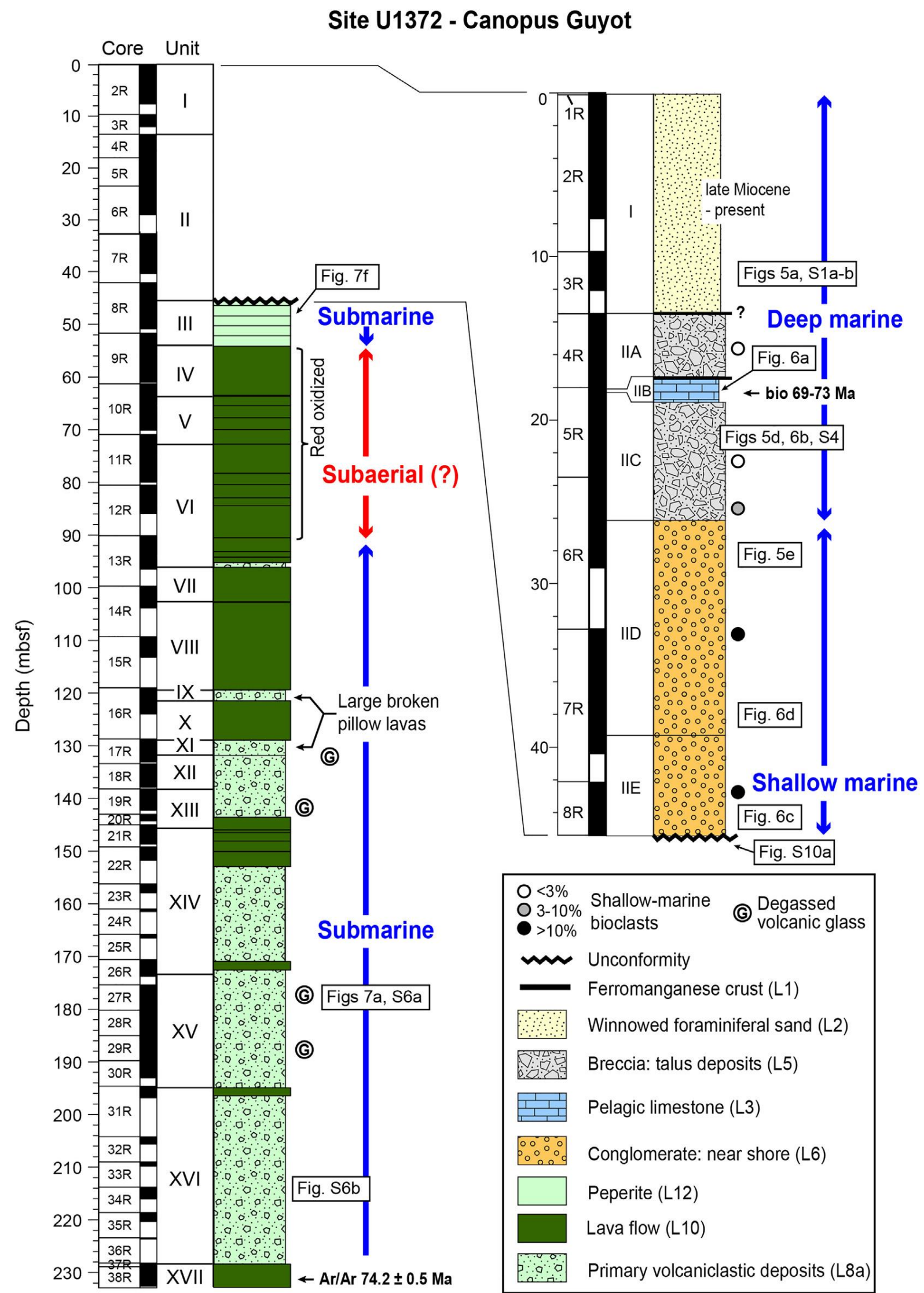

Fig 8. Lithostratigraphic column of Site U1372 on Canopus Guyot (modified from Koppers et al., 2012a). Age data are from Koppers et al. (2012a, 2012b). 
development of sea cliffs. The second sedimentary interval, Unit IX ( 85 to $64 \mathrm{mbsf}$ ) is predominantly composed of talus deposits (lithofacies 5 ) with minor shallow-marine bioclasts. This interval includes a $3.5 \mathrm{~m}$-thick bed of hyperconcentrated flow deposit(s) (lithofacies 9) that record high energy gravity flows on the slope of the volcano. Finally, the third, uppermost sedimentary interval occurs between approximately 42 and 38 mbsf just below the lava flows at the top of the volcanic basement. This interval includes hyperconcentrated flow deposits similar to those exposed in Unit IX (lithofacies 9) (Fig. 7D). Interbedded sedimentary and volcanic intervals in the basement at Site U1374 clearly show that this sequence was produced by volcanic activity along the coast of an island.

The volcanic basement is covered by an assemblage of sedimentary and volcanic deposits that rests upon lava flows along an erosional unconformity infilled by lithofacies 6 conglomerates (Fig. S10B). This unconformity closely resembles that observed at Site U1372 on Canopus Guyot and is also interpreted here as a major erosional unconformity, which formed after the main volcanic phase of the volcano. Overlying deposits include a conglomerate with abundant shallow-marine bioclasts (lithofacies 6), a thin interval of pelagic limestone (lithofacies 3) associated with reworked fragments/nodules of ferromanganese crust (lithofacies 1), reworked coarse lapilli vitric tuff with broken ammonoids (lithofacies 9, Fig. S8B), a primary vitric tuff with fluidal, vesicular clasts (lithofacies 9, Fig. $6 \mathrm{H}$ and Fig. S8A) capped by a $1 \mathrm{~cm}$-thick ferromanganese crust (lithofacies 1 ) and, finally, a summit deposit composed of winnowed foraminiferal sand (lithofacies 2). High vesiculation, flattened vesicles and grading structures in the juvenile tuff, together with undegassed glass that suggests emplacement at a depth of 250-550 mbsl (Nichols et al., 2014), are interpreted to reflect deposition from density currents proceeding from a nearby collapsing submarine eruption column (Simpson and McPhie, 2001; Cas et al., 2003). Deposition of pelagic limestone and ferromanganese nodules directly on top of the shallow-marine conglomerate and below the tuff indicates this submarine volcanism occurred several m.yr. after the island/shield stage of the seamount, therefore suggesting it represents a phase of rejuvenated, post-erosional magmatism. This interpretation is in good agreement with increased alkalinity of glass in the upper tuff unit (Nichols et al., 2014).

Shipboard biostratigraphic data from the pelagic limestone suggest a 75.2-75.7Ma age of deposition (Koppers et al., 2012a) that is difficult to reconcile with $71.1 \pm 0.9,70.5 \pm 0.7 \mathrm{Ma}$ and $69.5 \pm 0.4 \mathrm{Ma} \mathrm{Ar}$ Ar ages from lava flows in the volcanic basement at sites U1373 and U1374 (Koppers et al., 2012b). It is possible that biostratigraphic zonations used to constrain preliminary ages of the limestone are inaccurate in the South Pacific. In any case, biostratigraphic and geochronologic data are in broad agreement and, similarly to age data at Canopus Guyot, are consistent with rapid development of the upper Rigil Guyot. This development includes an early volcanic construction from submarine to subaerial conditions, followed by post-shield erosion, subsidence and drowning of the island, and finally short-lived volcanic rejuvenation in a deeper marine environment.

\subsection{Burton Guyot (Site U1376)}

Site U1376 is located close to the center of the summit platform of Burton Guyot and cross-cuts the southern side of a small conical feature that appears to have developed after formation of the flat summit (Fig. 4 and Fig. S9C). Similarly to previous drilling sites, the upper sequence of Burton Guyot includes abundant volcanic breccias, with minor lava flows, igneous intrusions and sedimentary deposits (Fig. 11). The volcanic basement (42 to $180 \mathrm{mbsf}$ ) is composed of vesicular hyaloclastites (lithofacies 8a) with lava flows (lithofacies 10) and subordinate crosscutting intrusive sheets (lithofacies 13). The basement above 57 mbsf includes rare, distinctive polymictic breccias and pillow lavas (lithofacies 11). The breccias include rare red-oxidized subrounded to rounded basalt clasts that attest for the occurrence of an emergent volcano during emplacement of the pillow lavas, but unlike drill sites at other seamounts no subaerial deposit has been preserved in the basement at Site U1376. Interbedded hyaloclastites and lava flows in the lower part of Site U1376 define a sequence similar to 


\section{Site U1373 - NE Rigil Guyot}

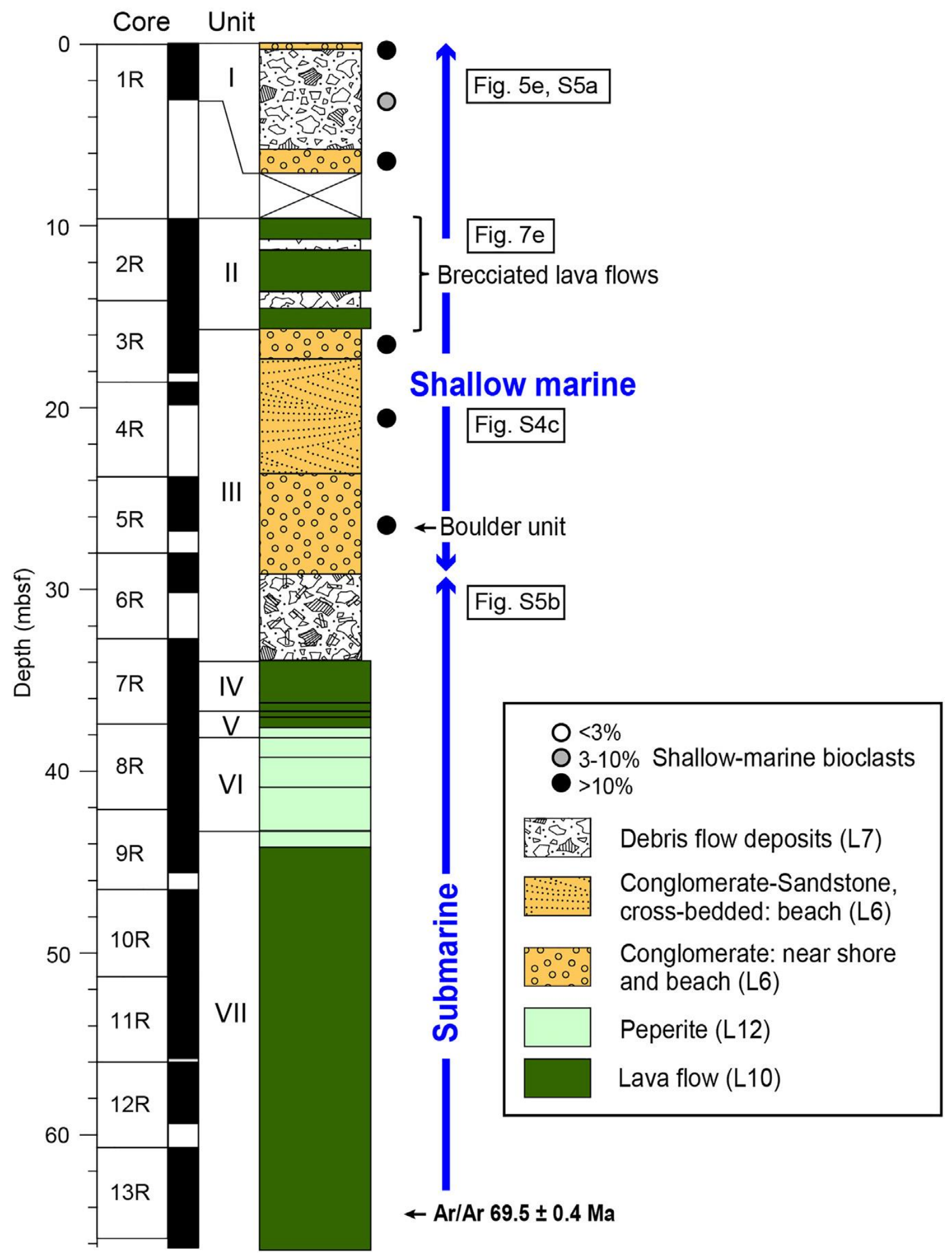

Fig 9. Lithostratigraphic column of Site U1373 on Rigil Guyot (modified from Koppers et al., 2012a). Age data are from Koppers et al. (2012a, 2012b).

that found in the basement of Canopus Guyot. This sequence is best accounted for by submarine fragmentation of lava flows in lava-fed deltas and/or submarine slopes of the volcano. Similar to 


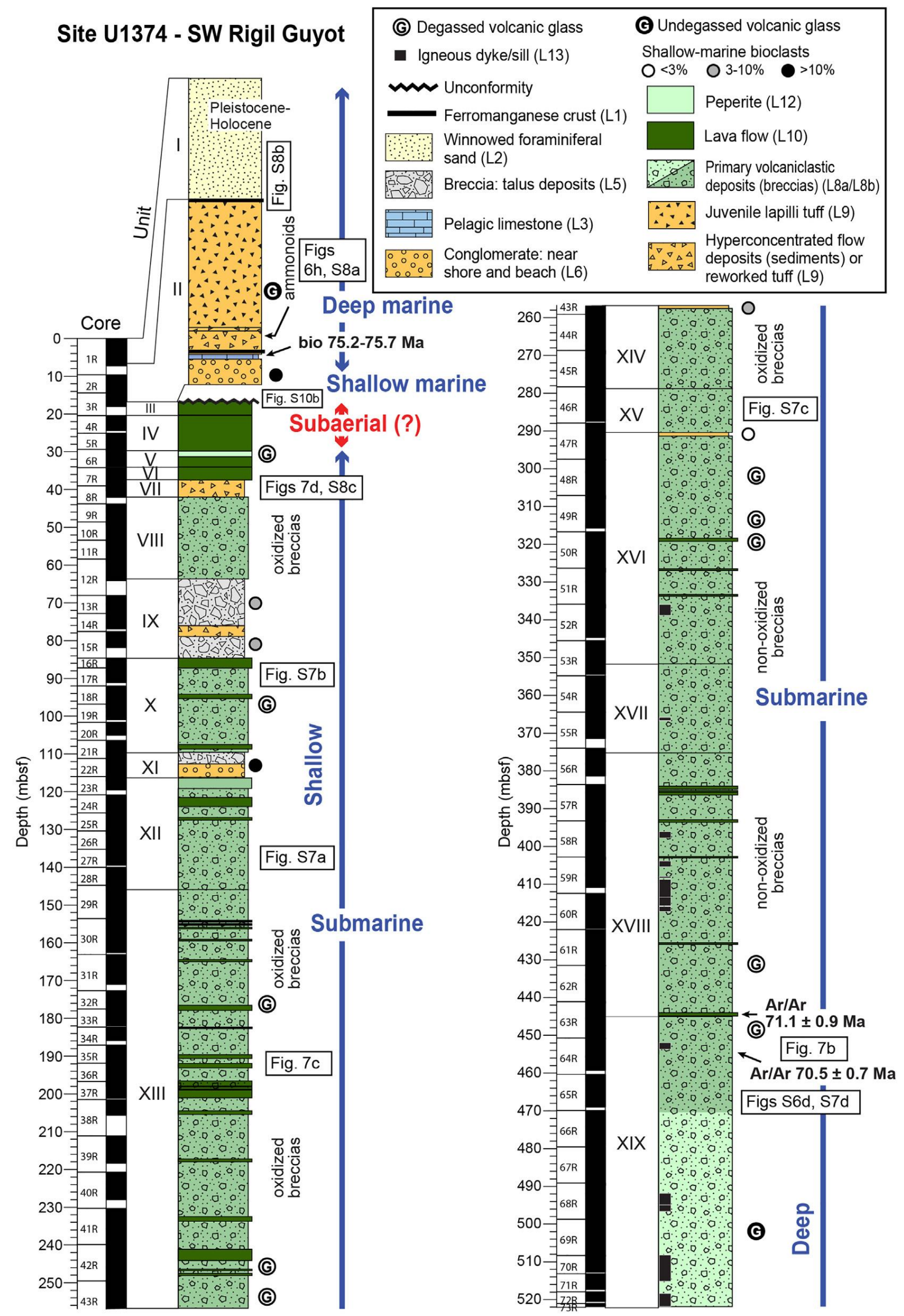

Fig 10. Lithostratigraphic column of Site U1374 on Rigil Guyot (modified from Koppers et al., 2012a). Age data are from Koppers et al. (2012a, 2012b). 
previous seamounts, degassing of the glass at Site U1376 suggests shallow, albeit poorly constrained ( 10-400 m), depth of eruption (Nichols et al., 2014) that is consistent with subaerial eruption followed by lava fragmentation in a shallow-marine environment.

The base of the sedimentary cover at Site U1376 is composed of shallow-marine conglomerate (lithofacies 6) that rests upon the volcaniclastic basement along a major erosional unconformity similar to those seen on top of the basement at other drilled seamounts (Fig. S10C). The conglomerate is rich in shallow-marine bioclasts and includes remarkable examples of micropeloidal cement (Fig. $6 \mathrm{E}-\mathrm{G})$.

Several hardgrounds/erosional surfaces are preserved in the conglomerate (Fig. S10C and Fig. 11), which suggest sedimentation in a high-energy, beach or shallow platform environment. Directly resting on top of the conglomerate is a coralline algal boundstone to rudstone (lithofacies 4) associated with construction of a $\sim 15 \mathrm{~m}$-thick coralline algal framework on top of the seamount. Basalt detritus in the limestone decreases up-section (Fig. S2), which reflects reduced erosion or epiclastic influx. The framework is capped by an interval of reworked and primary tuffs with rare lithic-rich turbidites (lithofacies 9). Fine to coarse tuffs resting directly on top of the limestone in Unit ID have dewatering structures (Fig. S8D), but were not reworked by bottom/wave currents. Most of units IB and IC are composed of hyperconcentrated flow deposits composed of lithic to vitric lapilli tuff; several erosional unconformities occur in these deposits. This facies is similar to the vitric tuff encountered at the top of Site U1374 on Rigil Guyot. It is also interpreted here as primary volcanic deposit emplaced in a deeper marine environment after initial subsidence of the seamount (i.e., post-erosional submarine volcanic activity). The interpretation of this facies is further supported by the conical structure on top of the guyot (Fig. S9C), and 120-350 m depth of eruption constrained by volatile contents in fresh glass fragments (Nichols et al., 2014). The uppermost sedimentary deposits recovered at Site U1376 include a succession of fine to coarse bioturbated tuff and sandy lithic turbidites (lithofacies 9)with four ferromanganese crusts of 1-2 cm thickness (lithofacies 1 ). These crusts suggest this sequence records a long interval of non-deposition punctuated by rare turbidity events and nearby influence from sporadic volcanic activity of undefined origin.

Only limited age constraints are available for Burton Guyot. A dyke in the lower part of the basement was dated to $64.05 \pm 0.45 \mathrm{Ma}$ by Ar-Ar dating (Koppers et al., 2012b). Shipboard observations support the occurrence of a large gastropod possibly belonging to the Maastrichtian-Eocene, Januncia genus, in the lowermost part of the sedimentary sequence (Subunit IIB) (S. Sano and P.W. Skelton personal observation). Overall, preceding observations document a short period of shield/post-shield volcanic activity followed by (i) a more extended period of erosion and subsidence coupled with development of algal frameworks and (ii) post-erosional submarine volcanism after submergence of the island.

\section{DISCUSSION AND IMPLICATIONS FOR THE FORMATION OF GUYOTS}

Lithostratigraphic results from Canopus, Rigil and Burton guyots that formed between ca. 74 and 64 Ma along the Louisville seamount chain depict a remarkably consistent geological evolution during the last ca. $5 \mathrm{Ma}$ of the main period of magmatic activity of the volcanoes and their subsequent drowning. Main lithological changes reflect a clear transition from (i) a predominantly constructional, volcanic stage associated with the emplacement of juvenile/primary volcaniclastic deposits and lava flows to (ii) a predominantly erosional stage, associated with the emplacement of sedimentary volcaniclastic deposits, and minor biogenic sediments and post-erosional submarine volcanic products. Although this broad evolution pattern is generally expected during the formation of oceanic islands globally (e.g., Schmidt and Schmincke, 2000; Staudigel and Clague, 2010; Staudigel and Koppers, 2015), the lithostratigraphy of the upper Louisville Seamounts offers a novel (direct) insight into the formation of high-latitude guyots on a fast-moving plate. 


\section{Site U1376 - Burton Guyot}



Fig 11. Lithostratigraphic column of Site U1376 on Burton Guyot (modified from Koppers et al., 2012a). Age data are from Koppers et al. (2012a, 2012b). 


\subsection{Erosional summit platform}

In the absence of summit carbonate platform (i.e., drowned atoll), the flat top of Pacific guyots is generally interpreted as the result of erosion at sea level with the development of extended wave planation surfaces (Hess, 1946). To date, observations that support this erosional interpretation consist essentially of the occurrence of well-rounded clasts collected by dredging or observed during submarine dives on summit platforms (e.g., Carsola and Dietz, 1952; Hamilton, 1956; Budinger, 1967; Paduan et al., 2009). In this context, the recognition of erosional surfaces in the uppermost stratigraphy of Louisville guyots is significant to characterize erosional processes at the end of the main volcanic phase of volcanic islands. Erosional surfaces are typical of rocky-shore environments, but poor stratigraphic preservation in this type of setting makes them particularly rare in the geological record (Felton, 2002; Sheppard, 2007). It is therefore remarkable that 3 of the 4 studied IODP drill sites (U1372, U1374 and U1376) expose a clear erosional boundary between a constructional effusive and intrusive igneous basement and a cover with shallow-water epiclastic deposits (Figs. 9-11, Fig. S10). Stacked lava flows directly below erosional boundaries and shallowmarine coastal deposits support preservation of a subaerial shield building phase on at least 2 of the 3 studied guyots. Occurrence of conglomerate and beach/coastal deposits just above the erosional boundary is clear evidence for post-shield coastal erosion on top of the volcanoes before submergence. Another erosional surface could occur at Site U1373 on top of Unit II, but it was probably not sampled due to poor recovery in this part of the seamount. The occurrence of post-shield erosional boundaries in the summit of Louisville seamounts is a significant observation that is consistent with wave planation of ancient islands. High wave energy conditions at high latitude could have facilitated strong marine erosion in the coastal environment of Louisville islands. Wave planation is also consistent with the stellate morphology of the seamounts, in which ridges that probably corresponds to rift zones are truncated by summit platforms (Figs. 2-4). The absence of paleosol in the lava stacks of Louisville seamounts could reflect limited weathering and terrestrial erosion in a highlatitude cold and/or arid environment. However, debris and hyperconcentrated flow deposits as well as shallow-marine conglomerates in the studied sequences do attest for syn-volcanic and postvolcanic subaerial and coastal erosion of islands. These erosional processes likely contributed to shaping the final morphology of the summit of the volcanoes (e.g., Smoot, 1995; Hildenbrand et al., 2008; Woodroffe, 2014), before final wave planation and drowning.

Due to evidence for erosion on top of shield lava flows, the pre-erosional size and shape of emergent Louisville volcanoes cannot be accurately reconstructed based on available data. However, volatile contents in glassy rims of intrusive sheets of Burton and Rigil guyots record emplacement at b170 m in the volcanic basement (Nichols et al., 2014; assuming that volcaniclastic piles were at or above sea level at the time of intrusion). This suggests that Louisville islands were formed by relatively small mergent edifices (possibly b500mabove sea level). A small island size is also consistent with the thin (b80 m) stacks of lava flows below interpreted planation surfaces. Interestingly, these stacks are thinner than those drilled during ODP Leg 197 on Detroit, Nintoku and Koko guyots along the northern part of the Hawaiian-Emperor seamount chain. Although these early Eocene-Cretaceous guyots formed in a tectonic and environment setting similar to that of Louisville seamounts (i.e., fast-moving plate with limited reef formation at high-latitude), the summit stratigraphy of these HawaiianEmperor guyots down to 350 to 900 mbsf exhibits a ten-fold higher lava/volcaniclastic ratio than that at Louisville seamounts, with lava stacks commonly N120 m thick (ODP Leg 197 Shipboard Scientific Party, 2002a, 2002b, 2002c, 2002d). In addition, the summit platforms of Louisville guyots range in diameter between approximately 5 and $15 \mathrm{~km}$ (Figs. 2-4), whereas those of Hawaiian-Emperor guyots drilled during Leg 197 have diameters of approximately 40 to $80 \mathrm{~km}$ (Ryan et al., 2009). Overall these observations suggest that volcanic islands associated with the formation of Louisville guyots were much smaller than those of Hawaiian- Emperor guyots. We propose below that this was associated 
with two different modes of emergence of these volcanoes, with more abundant lava-fed deltas and the development of more extended shelves around emergent Louisville volcanoes.

\subsection{Constructional volcanic summit platform}

It has been hypothesized that the summit platform of guyots in the Pacific is not primarily shaped by erosional processes, but predominantly reflects constructional volcanic processes (Nayudu, 1962; Christensen and Gilbert, 1964; Simkin, 1972; Natland, 1976). Although some models date back to the early days of modern volcanology and have been disproved by more recent studies (e.g., Christensen and Gilbert, 1964; Murtagh and White, 2013), there are several volcanic mechanisms that could explain the formation of a mostly flat surface on top of an insular to submarine volcano. A first hypothesis is that guyots inherit their flat summit from subaerial effusive mechanisms associated with circumferential feeder vent systems similar to those of the modern Galapagos Islands (Simkin, 1972). In this scenario, a summit promontory is formed by stacking of lava flowing inward from a ring feeder system at the center of the volcanic edifice. However, this hypothesis is in disagreement with the stellate morphology of Louisville guyots that suggests that the volcanoes developed with radial rift systems (Figs. 2-4). A second, broadly similar hypothesis is that volcanic terraces of large size (up to tens of kilometers wide) can develop on top of submarine volcanoes due to lava stacking. In this case, superposition of the lavas is controlled by deflation of lava flows with the formation of levees that will act as barriers and control the spatial extent of subsequent lava flows (Clague et al., 2000; Geist et al., 2008). Similar structures could also possibly develop on the top of guyots due to submarine tube-fed lava deltas (Chaytor et al., 2007). Although it is not possible to completely rule out extensive lava stacking during early (pre-erosional) construction of partly eroded volcanic edifices, it is very unlikely that this process played a significant role among Louisville seamounts. Significant lava stacking seems at odd with the characteristics and stratigraphic context of lava intervals and individual lava flows preserved in the studied drill sites, which are very thin and are interbedded within a predominantly volcaniclastic basement with local evidence for shallow-marine environments. A third hypothesis that could account for the formation of a summit platform is the collapse and infill of calderas on the volcanoes (e.g., Portner et al., 2014). However, the absence of hydrothermal alteration, hydrothermal deposits and polymictic breccia in the uppermost volcanic basement of Louisville seamounts (Koppers et al., 2012a; this study) are not consistent with this interpretation.

Another constructional hypothesis, which is surprisingly consistent with lithostratigraphic (volcanic and sedimentary) characteristics, palaeo-environmental conditions, and glass volatile contents of the studied Louisville seamounts, is that the development of a summit platform could be primarily controlled by construction of an emergent volcano with the establishment of extended lava-fed deltas in the coastal environment. The observation of hyaloclastite and isolated pillow lobes on top of guyots in the NE Pacific and along the Line Islands and Mid-Pacific Mountains nourished the early idea that lavas brecciating during their entry in the sea or during development of submarine terraces could control the formation of summit platforms (Nayudu, 1962; Natland, 1976). Our lithostratigraphic observations and the occurrence of degassed hyaloclastite and glass fragments (Nichols et al., 2014) in the predominantly volcaniclastic upper Louisville guyots clearly indicate that the uppermost hundred meters of the drilled volcanoes developed in subaerial to shallow-marine environments with locally unstable slopes and/or effective quench granulation and autobrecciation of basaltic lavas. As commented above, these characteristics and lithostratigraphic relations in the uppermost Louisville guyots are typical of lava-fed deltas. Shallow-marine shelves can extend at least several hundreds of meters around volcanically active islands in the Atlantic due to progradation of lava flows into the sea and formation of lava-fed deltas (e.g., Mitchell et al., 2008; Quartau et al., 2012). Similar deltas can also develop locally around the Hawaiian Islands (e.g., Moore et al., 1973; Mattox and Mangan, 1997; Tribble, 1991), and have been drilled in the upper part of Hawaiian-Emperor guyots (ODP Leg 197 Shipboard Scientific Party, 2002a, 2002d). The development of lava-fed deltas is controlled by several 




Fig 12. Simplified lithostratigraphy of Louisville cores and models of evolution of Louisville-type and Hawaiian-type guyots. Island stage $\mathbf{2}$ is subdivided into a syn-volcanic stage $\mathbf{2 a}$ and post-volcanic stage $\mathbf{2 b}$ applicable to Louisville cores.

interdependent factors such as coastal morphology, water depth, wave energy level, lava viscosity, and lava effusion rates (e.g., Watton et al., 2013). Unfortunately many of these factors cannot be constrained in the studied guyots, and this limits our ability to determine precisely in which context and under which conditions Louisville deltas emplaced.

An alternate way to assess the role of lava-fed deltas during the formation of Louisville seamounts is to compare our results with the lithostratigraphy of volcanoes that emplaced in a similar tectonic setting and environment, such as high-latitude Hawaiian-Emperor guyots drilled during ODP Leg 197. A significant difference exists between these two classes of volcanoes: with the exception of the 
unusual case of ODP Site 1203 at the junction of two volcanic edifices on Detroit seamount, cores from Hawaiian-Emperor guyots do not contain thick lava-fed delta deposits (or other types of volcaniclastic deposits). It is possible that cores retrieved from Louisville and Hawaiian-Emperor guyots do not record exactly the same stages of formation of volcanic islands, but the larger abundance of lava-fed delta deposits in Louisville guyots and their occurrence below shield lava flows documents abundant emplacement of lava-fed deltas during the emergence of Louisville volcanoes. At Site U1374 on Rigil guyot, lava-fed delta deposits occur on top of undegassed hyaloclastites, and below shallow-marine deposits and shield lavas (Fig. 10). Although coastal erosion is commonly associated with the emplacement of lava-fed deltas (e.g., Quartau et al., 2015, 2016; Marques et al., 2016), stratigraphic relations at Site U1374 supports delta emplacement during long-term growth (not erosion) of an active, probably subsiding volcano. Therefore, given the particular volcaniclastic nature and stratigraphy of the studied Louisville sequences (compared to Hawaiian-Emperor guyots that formed in a similar setting), and the nature of the shelf of some modern volcanic islands, we propose that Louisville seamounts exemplify a particular mode of formation of guyots at high latitude on a fastmoving plate. In this model, the summit platform of a guyot forms predominantly through: (1) a synvolcanic, pre-shaping phase during which a small-sized central shield volcano is surrounded by relatively extended lava-fed delta shelves, and (2) post-volcanic planation of the shield volcano due to subaerial and shallow-marine coastal erosion (Fig. 12). This new model is discussed below with a comparison to the well-accepted model of formation of Hawaiian-type guyots that represent a class of volcano much larger than Louisville seamounts and the majority of other island-building volcanoes in the Pacific.

\subsection{Model of formation of guyots}

The formation of guyots can be broadly subdivided into 3 main geological stages that reflect fundamental changes in environmental (i.e., not necessarily volcanic or geochemical) conditions and lithological characteristics associated with the growth and subsidence of volcanoes: (1) a seamount stage; (2) an island stage; and (3), a guyot stage. This subdivision is illustrated and correlated to a lithostratigraphic synthesis of the studied Louisville sequences in Fig. 12.

\subsubsection{Seamount stage}

The seamount stage reflects growth of the volcano in submarine conditions, before emergence of a durable island. This stage can be further subdivided into lower and upper seamount stages. The lower seamount stage is associated with eruption in deep water and limited exsolution of magmatic volatiles and magma fragmentation. This stage is comparable to the Loihi Seamount for Hawaiian volcanoes (e.g., Clague and Dalrymple, 1987) and probably the majority of small-sized seamounts globally. Its main lithological characteristic is the occurrence of abundant pillow lavas with subordinate volcaniclastic deposits. To our knowledge the lower seamount stage has only been observed at the core of a large volcano during the Hawaiian Drillling Scientific Project 2 in Mauna Kea at a depth of nearly $2 \mathrm{~km}$ (e.g., Garcia et al., 2007) and in the uplifted basement of La Palma Island (Staudigel and

Schmincke, 1984). It is not documented by sequences drilled in the upper $500 \mathrm{~m}$ of Louisville seamounts.

The upper seamount stage is associated with lithostratigraphic transition from lava-dominated to breccia-dominated volcanic deposits. This transition reflects increase in magmatic degassing during shallowing of the volcano, with promotion of magma fragmentation and formation of more abundant primary volcaniclastic deposits. In Louisville seamounts this phase has only been recognized at Site U1374 on Rigil Guyot (Fig. 12), where an eruption depth of 300-550 m is supported by undegassed hyaloclastites (Fig. 10; Nichols et al., 2014). 
The end of the seamount stage is marked by Surtseyan volcanism during breaching of the sea level by the seamount. Although this type of activity is generally considered to be associated with the formation of volcanic islands, clear primary Surtseyan deposits have not been recovered/preserved in the studied Louisville sequences. Missing evidence for Surtseyan activity is in fact common in the geological record of oceanic islands (e.g., Buchs et al., 2011; Ramalho et al., 2015). We propose here that this apparent lack of evidence is an observational bias resulting from the very small volume of Surtseyan volcanic products expected to be emitted at the transition between the upper seamount and island stages. Surtseyan activity, although being temporally and spatially very limited, marks a fundamental moment in the evolution of a guyot because it corresponds to the establishment of an embryonic island and the beginning of a very distinct, subaerial regime of volcanism with the development of a shield volcano.

From a lithostratigraphic perspective, the seamount stage of Louisville guyots is anticipated to closely resemble that of larger Hawaiian volcanoes (Fig. 12). However, geochemical data from Louisville indicate that basalts and hyaloclastites from the upper seamount and island stages have alkaline to transitional tholeiitic affinities (Hawkins et al., 1987; Beier et al., 2011; Koppers et al., 2012a; Nichols et al., 2014; Vanderkluysen et al., 2014; Dorais, 2015). This contrasts with the upper seamount and island stages of Hawaiian volcanoes that have a predominant tholeiitic composition (e.g., Feigenson et al., 2003; Rhodes and Vollinger, 2004). This clearly indicates that fundamental petrological differences accompany the formation of islands in Louisville-type and Hawaiian-type volcanoes. Significantly, this cannot be accounted for without modification of the traditional model of oceanic island formation.

\subsubsection{Island stage}

The beginning of the island stage of guyots is associated with initiation of a durable subaerial shield volcano. Establishment of the island occurs only when the rate of volcanic growth supersedes that of shoreline retreat. Island formation is in fact intrinsically controlled by a complex, dynamic interplay between effusive volcanism at the top of the volcano, inflation of the volcano by subvolcanic intrusions, coastal and subaerial erosion, possible flank collapses, sea level change and subsidence of the volcano (e.g., as well documented in the Atlantic Ocean setting, Mitchell et al., 2008; Quartau et al., 2012, 2014; Ramalho et al., 2013, 2015). We introduce here the idea that two main types of insular volcanoes (and ultimately guyots) can develop on a fast-moving plate depending on the efficiency of constructional magmatic processes to overcome erosional and/or subsidence effects (Fig. 12).

Hawaiian-type volcanoes are associated with very efficient magmatic growth relative to erosional and/or subsidence effects, which ultimately results in a large, several $\mathrm{km}$-thick shield volcano on top of seamount sequences (e.g., ODP Leg 197 Shipboard Scientific Party, 2002a, 2002b, 2002c, 2002d; Garcia et al., 2007). This type of island forms a large rocky promontory surrounded by a submarine volcaniclastic apron of primary volcanic and sedimentary deposits, as commonly depicted in the archetypal model of formation of Hawaiian Islands (e.g., Staudigel and Clague, 2010). Syn- and postvolcanic flank collapses can contribute to significant reduction of the size of the volcanic edifice (Moore et al., 1989). Formation of a similar (albeit not identical) type of insular volcano could occur with both lower magmatic growth and subsidence. Such conditions can notably be met by hotspot volcanoes formed on slow-moving (Atlantic-like) plates, e.g., the Canary Islands (Carracedo, 1999).

In contrast, our model hypothesizes that the island stage of Louisville-type guyots is characterized by lower magmatic growth relative to subsidence and/or erosion than Hawaiian-type volcanoes. Two main arguments support this idea: (1) alkaline magmatism such as that observed in the late seamount and island stages of Louisville seamounts is generally indicative of incipient magmatic waning in large intraplate ocean volcanoes on a fast-moving plate (e.g., Clague and Dalrymple, 1987; Staudigel and Clague, 2010; Staudigel and Koppers, 2015); and (2) Louisville islands were most likely smaller than 
those of the Hawaiian-Emperor guyots that formed in a similar tectonic and environment setting (see discussion above). Lower magmatic growth in the island stage of Louisville seamount means that the effects of erosion and/or subsidence were relatively stronger compared to Hawaiian-type volcanoes, and this could have triggered high frequency coastal retreats and the formation of ephemeral shallowmarine erosional platforms (e.g., Ramalho et al., 2013) during the early stages of island formation. In our model, such platforms are considered to have helped promote the development of shallowmarine lava-fed deltas and, ultimately, the establishment of relatively extended constructional volcaniclastic shelves around a small emergent shield volcano (Fig. 12). Ephemeral shallow-marine erosional platforms are expected to be difficult to recognize in the lithostratigraphic record. In the studied sequences, they could be associated with recurrent volcanoclastic deposits that include reworked shallow-marine bioclasts and/or oxidized/rounded basalt clasts in the basement at Sites U1374 and U1376. Sequences dominated by degassed, shallow-marine to subaerial juvenile volcaniclastic deposits and lava flows can be used to define a syn-volcanic sub-stage during the island stage of Louisville-type guyots (stage 2a in Fig. 12). Stratigraphic relations observed between lava-fed delta deposits, shallow-marine conglomerates, and lava flows at Sites U1372 and U1374 (Figs. 8 and 10) suggest general progradation of the shield volcano on top of deltas and coastal deposits during this stage, before development of major, post-shield wave planation surfaces. In contrast, Sites U1373 and U1376 suggest that protracted phases of coastal retreat could have locally occurred before the end of the shield volcanic phase (Figs. 9 and 11). These contrasting lithostratigraphic patterns are best accounted for by a dynamic syn-volcanic coastal environment controlled by closely competing constructional and destructive processes as proposed here for a fast-moving plate setting, and similar to models of island formation in a slow-moving plate setting (e.g. Ramalho et al., 2013).

The end of the island stage in both Hawaiian- and Lousiville-type guyots is associated with increased erosional processes after magmatic cessation. Very tall (several $\mathrm{km}$-high) subaerial shield volcanoes in Hawaiian-Type islands means that subaerial erosion and wave planation will probably be the dominant processes controlling the formation of the summit guyot platform in a high-latitude environment. In comparison, subsiding small shield volcanoes surrounded by submarine volcanic shelves at Louisvilletype islands will undergo more limited erosion and post-volcanic planation before submergence. Postvolcanic erosional processes are associated in the lithostratigraphic record with distinctive shallowmarine conglomerates and talus deposits, which can be used to define a post-volcanic sub-stage during the island stage of Louisville-type (and probably also Hawaiian-type) guyots (stage $2 \mathrm{~b}$ in Fig. 12).

Although beyond the main scope of this study on the formation of high-latitude guyots, an important aspect of the end of the island stage is the development of reefs/organic frameworks on the subsiding volcanic basement. Thick shallow-marine carbonate rocks at the top of a guyot could be used to define a final reef-building phase at the end of the island stage. Such a stage has not been documented on drilled Louisville seamounts and seems to be restricted to Guyot $168.0^{\circ} \mathrm{W}$ along Louisville seamount chain (Lonsdale, 1988; Ebuna, 2011). In favourable (e.g. tropical) environmental conditions reefbuilding organisms can form atolls and thick promontories that will have a predominant control on the final shape of the summit platform of guyots (Winterer et al., 1993). Coralline red algal framework in Subunit IIA at Site U1376 (Fig. 11) represents a relatively thin and probably local deposit that is unlikely to be associated with the development of an extended biogenic platform on top of Burton Guyot. Reef development can affect erosion during syn-volcanic and post-volcanic island stages by promoting dissipation of the swell and the energy of waves along the coastal environment (e.g., Ramalho et al., 2013). Limited organic framework development in the high-latitude environment could therefore have been another factor controlling the budget of magmatism growth versus erosion of the studied Louisville guyots. However, reliably assessing the mode and extent of reef/organic framework development and its link to environmentally-controlled coastal erosional processes would 
require drilling/sampling of the sedimentary cover and volcanic basement of a larger population of Louisville-type and Hawaiian-type guyots that formed in a large range of latitudes.

\subsubsection{Guyot stage}

The guyot stage starts after complete drowning of the volcanic island or atoll. This stage is associated with pelagic biogenic and detrital sedimentary deposits and formation of ferromanganese crusts. In Louisville-type seamounts a phase of post-erosional (rejuvenated) volcanism is well documented by juvenile volcaniclastic deposits (this study, Sites U1374 and U1376), which are emplaced at a depth of several hundred of meters and are characterized by strongly alkaline affinities (Nichols et al., 2014). Hawaiian volcanoes differ from these observations in that they lack post-erosional rejuvenated volcanism after submergence of the island (e.g., Clague and Dalrymple, 1987). However, seamount chains in the Pacific document a complicated history of magmatic rejuvenation with sometimes multiple cycles of renewed activity (e.g., Natland and Winterer, 2005). Although the exact causes for this magmatism remain unclear, new constraints from Louisville seamounts and their comparison with Hawaiian volcanoes confirm that considerable variability can occur regarding the timing and, possibly, origins of late stage volcanic activity along seamount chains.

\section{CONCLUSIONS}

The lithostratigraphy of the summit of Canopus, Rigil and Burton guyots of the Louisville seamount chain offers a novel insight into the formation of volcanic islands and guyots. The nature and stratigraphic distribution of 13 sedimentary and volcanic lithofacies reveal fundamental environmental and volcanic differences in the formation of high-latitude Louisville seamounts and Hawaiian-Emperor guyots that formed in similar tectonic and environmental conditions. This suggests that Louisville guyots represent a new class of island-building volcano in a fast-moving plate context, in which the island stage is associated with the formation of a smaller island composed of a central shield volcano surrounded by relatively large shallow-marine shelves with lava-fed deltas. We propose that the difference between Louisville-type volcanoes and Hawaiian-type volcanoes reflects dynamic competition between magmatic growth, erosion and/or subsidence during the island stage of these volcanoes, with a lower ratio of magmatic growth versus erosion and/or subsidence at Louisville-type volcanoes. This model is in good agreement with existing lithological and geochemical constraints from Louisville and the Hawaiian-Emperor seamount chains as well as surficial observations of numerous other guyots and volcanic islands in the Pacific and Atlantic Oceans. Considering the unusually large magma production at the Hawaii hotspot, Louisville-type volcanoes could therefore represent the most common mode of formation of guyots in the Pacific. Recognition of post-shield erosional boundaries at Louisville is consistent with formation of the summit platform of high-latitude guyots by post-volcanic wave planation. However, new lithostratigraphic constraints suggests that, on small volcanic islands formed in a fast-moving plate setting, a significant fraction of the summit morphology could be inherited from the formation of shelves with lava-fed deltas. Because our definition of Louisville-type volcanoes is based on lithostratigraphic criteria, the validity of our model could be relatively easily tested through additional drilling of guyots and/or investigation of circumPacific accreted oceanic islands (e.g., Buchs et al., 2011). In addition, determining the nature of volcaniclastic aprons around Pacific guyots could help better characterize the effects of constructional vs erosional processes during the formation of a summit platform. Significantly, our study shows that the evolution of island building volcanoes is best described in a framework reflecting changes of environmental conditions, e.g. using following stages: (i) early seamount; (ii) late seamount; (iii) island; and (iv) guyot. New IODP constraints from Louisville seamounts clearly show that geochemical criteria (e.g. alkaline vs tholeiitic magmatism) can be misleading in terms of volcanic and geological evolution of volcanic islands. 
Supplementary data to this article can be found online at https://doi.org/10.1016/i.jvolgeores.2017.12.019.

\section{ACKNOWLEDGMENTS}

We thank Editor Kelly Russel and reviewers Dennis Geist and Ricardo Ramalho for their very constructive comments that helped us improve this manuscript. We thank the captain and crew of JOIDES Resolution for their remarkable work and help during IODP Expedition 330.We also thank cochief scientists Anthony Koppers and Toshitsugu Yamazaki, and staff scientist Jörg Geldmacher. Early observations and discussions with the scientific crew on IODP Expedition 330 were greatly appreciated; this study would not have been possible without their dedicated efforts onboard. We thank L. Vanderkluysen for discussion on pre-IODP expeditions along the Louisville seamount chain and sharing his views on the nature of Louisville volcanoes. Participation of DMB, RW and SS in Expedition 330 has been supported by the Australia-New Zealand IODP Consortium (ANZIC), European Consortium for Ocean Research Drilling (ECORD), and Japan Drilling Earth Science Consortium (JDESC).

\section{REFERENCES}

Abbott, P.L., Hanson, A.D., Thomson, C.N., Logue, D.L., Bradshaw, K.D., Pollard, W.J., Seeliger, T.E., 1993. Geology of the Paleocene Sepultura Formation, Mesa de la Sepultura, Baja California. Cienc. Mar. 19, 75-93.

Abouchami, W., Goldstein, S.L., Gazer, S.J.G., Eisenhauer, A., Mangini, A., 1997. Secular changes of lead and neodymium in central Pacific seawater recorded by a Fe.Mn crust. Geochim. Cosmochim. Acta 61, 3957-3974.

Baccelle, L., Bosellini, A., 1965. Diagrammi per la stima visiva: della composizione percentuale nelle rocce sedimentarie. Annali dell'Università di Ferrara (Nueva Serie), Sezione 9, Scienze Geologiche e Paleontologiche. Università degli studi di Ferrara, pp. 59-62.

Beier, C., Vanderkluysen, L., Regelous, M., Mahoney, J.J., Garbe-Schönberg, D., 2011. Lithospheric control on geochemical composition along the Louisville Seamount Chain.

Geochem. Geophys. Geosyst. 12, Q0AM01.

Benninger, L.M., Hein, J.R., 2000. Diagenetic Evolution of Seamount Phosphorite. Society for Sedimentary Geology.

Buchs, D.M., Arculus, R.J., Baumgartner, P.O., Ulianov, A., 2011. Oceanic intraplate volcanoes exposed: example from seamounts accreted in Panama. Geology 39, 335-338.

Buchs, D., Hoernle, K., Grevemeyer, I., 2015. Seamounts. In: Harff, J., Meschede, M., Petersen, S., Thiede, J. (Eds.), Encyclopedia of Marine Geosciences. Springer, Netherlands, pp. 1-11.

Budinger, T.F., 1967. Cobb seamount. Deep Sea Res. Oceanogr. Abstr. 14, 191-201. Carracedo, J.C., 1999. Growth, structure, instability and collapse of Canarian volcanoes and comparisons with Hawaiian volcanoes. J. Volcanol. Geotherm. Res. 94, 1-19.

Carsola, A.J., Dietz, R.S., 1952. Submarine geology of two flat-topped northeast Pacific seamounts. Am. J. Sci. 250, 481-497.

Cas, R.A.F., Yamagishi, H., Moore, L., Scutter, C., 2003. Miocene submarine fire fountain deposits, Ryugazaki Headland, Oshoro Peninsula, Hokkaido, Japan: implications for submarine fountain dynamics and fragmentation processes, explosive subaqueous volcanism. Am. Geophys. Union 299-316.

Chaytor, J.D., Keller, R.A., Duncan, R.A., Dziak, R.P., 2007. Seamount morphology in the Bowie and Cobb hot spot trails, Gulf of Alaska. Geochem. Geophys. Geosyst. 8, Q09016.

Christensen, M.N., Gilbert, C.M., 1964. Basaltic cone suggests constructional orig;in of 
some Guyots. Science 143, 240-242.

Clague, D.A., Dalrymple, G.B., 1987. The Hawaiian-Emperor volcanic chain, part I, geologic evolution. In: Decker, R.W.,Wright, T.L., Stauffer, P.H. (Eds.), Volcanismin Hawaii. U.S. Government Printing Office, pp. 5-54.

Clague, D.A., Moore, J.G., Reynolds, J.R., 2000. Formation of submarine flat-topped volcanic cones in Hawai'i. Bull. Volcanol. 62, 214-233.

Clague, D.A., Paduan, J.B., Davis, A.S., 2009. Widespread strombolian eruptions of midocean ridge basalt. J. Volcanol. Geotherm. Res. 180, 171-188.

Contreras-Reyes, E., Grevemeyer, I., Watts, A.B., Planert, L., Flueh, E.R., Peirce, C., 2010.

Crustal intrusion beneath the Louisville hotspot track. Earth Planet. Sci. Lett. 289,

323-333.

Cullen, D.J., Burnett, W.C., 1986. Phosphorite associations on seamounts in the tropical southwest Pacific Ocean. Mar. Geol. 71, 215-236.

Darwin, C., 1842. The Structure and Distribution of Coral Reefs: Being the First Part of the Geology of the Voyage of the Beagle, Under the Command of Captain Fitzroy, R.N., During the Years 1832-1836. Smith, Elder and Co., London 214 pp.

Deardorff, N.D., Cashman, K.V., Chadwick, W.W., 2011. Observations of eruptive plume dynamics and pyroclastic deposits from submarine explosive eruptions at NW

Rota-1, Mariana arc. J. Volcanol. Geotherm. Res. 202, 47-59.

Dickinson, W.R., 1998. Geomorphology and geodynamics of the Cook Austral island seamount chain in the South Pacific Ocean: implications for hotspots and plumes. Int.

Geol. Rev. 40, 1039-1075.

Dorais,M.J., 2015. Exploring themineralogical heterogeneities of the Louisville Seamount Trail. Geochem. Geophys. Geosyst. 16. https://doi.org/10.1002/2015GC005917.

Downey, N.J., Stock, J.M., Clayton, R.W., Cande, S.C., 2007. History of the Cretaceous Osbourn spreading center. J. Geophys. Res. Solid Earth 112, B04102. https://doi.org/ 10.1029/2006JB004550.

Dunham, R.J., 1962. Classification of carbonate rocks according to depositional texture. Mem. Am. Assoc. Pet. Geol. 1, 108-121.

Ebuna, D.R., 2011. Volcanic, Erosional, Tectonic, and Biogenic Peaks on Guyot Summit Plains in the Louisville Seamount Chain. Unpublished M.Sc. Thesis. University of California, San Diego, USA, p. 77.

Embry, A.F., Klovan, J.E., 1972. A Late Devonian reef tract on northeastern Banks Island, N. W.T. Bull. Can. Petrol. Geol. 19, 730-781.

Feigenson, M.D., Bolge, L.L., Carr, M.J., Herzberg, C.T., 2003. REE inverse modeling of HSDP2 basalts: evidence for multiple sources in the Hawaiian plume. Geochem.

Geophys. Geosyst. 4.

Felton, E.A., 2002. Sedimentology of rocky shorelines: 1. A review of the problem, with analytical methods, and insights gained from the Hulopoe Gravel and the modern rocky shoreline of Lanai, Hawaii. Sediment. Geol. 152, 221-245.

Flood, P., 1999. Development of northwest Pacific guyots: general results fromOcean Drilling Program legs 143 and 144. Island Arc 8, 92-98.

Flood, P.G., 2001. The 'Darwin Point' of Pacific Ocean atolls and guyots: a reappraisal. Palaeogeogr. Palaeoclimatol. Palaeoecol. 175, 147-152.

Folk, R.L., Leo Lynch, F., 2001. Organicmatter, putative nannobacteria and the formation of ooids and hardgrounds. Sedimentology 48, 215-229.

Garcia, M.O., Davis, M.G., 2001. Submarine growth and internal structure of ocean island volcanoes based on submarine observations of Mauna Loa volcano, Hawaii. Geology 29, 163-166.

Garcia, M.O., Haskins, E.H., Stolper, E.M., Baker, M., 2007. Stratigraphy of the Hawai'i Scientific Drilling Project core (HSDP2): anatomy of a Hawaiian shield volcano. 
Geochem. Geophys. Geosyst. 8, Q02G20.

Geist, D., Diefenbach, B.A., Fornari, D.J., Kurz, M.D., Harpp, K., Blusztajn, J., 2008. Construction of the Galápagos platform by large submarine volcanic terraces. Geochem.

Geophys. Geosyst. 9, Q03015.

Hamilton, E.L., 1956. Sunken Islands of the mid-Pacific Mountains. Geol. Soc. Am. Mem.

64, 1-92.

Hawkins, J.W., Lonsdale, P.F., Batiza, R., 1987. Petrologic evolution of the Louisville Seamount Chain, in: Keating, B.H., Fryer, P., Batiza, R., Boehlert, G.W. (Eds.), seamounts, islands, and atolls. Am. Geophys. Union 235-254.

Hein, J.R., Koschinsky, A., 2014. 13.11 - deep-ocean ferromanganese crusts and nodules A2 - Holland, Heinrich D. In: Turekian, K.K. (Ed.), Treatise on Geochemistry, Second Edition Elsevier, Oxford, pp. 273-291.

Hein, J.R., Yeh, H.-W., Gunn, S.H., Sliter, W.V., Benninger, L.M., Wang, C.-H., 1993. Two major Cenozoic episodes of Phosphogenesis recorded in equatorial Pacific seamount deposits. Paleoceanography 8, 293-311.

Heindel, K., Birgel, D., Brunner, B., Thiel, V., Westphal, H., Gischler, E., Ziegenbalg, S.B., Cabioch, G., Sjövall, P., Peckmann, J., 2012. Post-glacial microbialite formation in coral reefs of the Pacific, Atlantic, and Indian oceans. Chem. Geol. 304, 117-130. Hess, H.H., 1946. Drowned Ancient Islands of the Pacific Basin. Am. J. Sci. 244, 772-791. Hildenbrand, A., Gillot, P.-Y., Marlin, C., 2008. Geomorphological study of long-term erosion on a tropical volcanic ocean island: Tahiti-Nui (French Polynesia). Geomorphology 93, 460-481.

Hillgärtner, H., Dupraz, C., Hug, W., 2001. Microbially induced cementation of carbonate sands: are micritic meniscus cements good indicators of vadose diagenesis? Sedimentology 48, 117-131.

Hinchliffe, S., Ballantyne, C.K.,Walden, J., 1998. The structure and sedimentology of relict talus, Trotternish, northern Skye, Scotland. Earth Surf. Process. Landf. 23, 545-560.

Jakobsson, S., Thors, K., Vésteinsson, Á., Ásbjörnsdóttir, L., 2009. Some aspects of the seafloor morphology at Surtsey volcano: the new multibeam bathymetric survey of

2007. Surtsey Res. 12, 9-20.

Jerram, D.A., 2001. Visual comparators for degree of grain-size sorting in two and threedimensions. Comput. Geosci. 27, 485-492.

Jones, E.J.W., BouDagher-Fadel, M.K., Thirlwall, M.F., 2002. An investigation of seamount phosphorites in the Eastern Equatorial Atlantic. Mar. Geol. 183, 143-162.

Jutzeler,M., Marsh, R., Carey, R.J., White, J.D.L., Talling, P.J., Karlstrom, L., 2014. On the fate of pumice rafts formed during the 2012 Havre submarine eruption. Nat. Commun. 5, 3660. https://doi.org/10.1038/ncomms4660.

Kokelaar, P., 1986.Magma-water interactions in subaqueous and emergent basaltic volcanism. Bull. Volcanol. 48, 275-289.

Koppers, A.A.P., Yamazaki, T., Geldmacher, J., 2010. Louisville Seamount Trail: implications for geodynamic mantle flow models and the geochemical evolution of primary hotspots. IODP Sci. Prosp. 330. https://doi.org/10.2204/iodp.sp.330.2010.

Koppers, A.A.P., Gowen,M.D., Colwell, L.E., Gee, J.S., Lonsdale, P.F., Mahoney, J.J., Duncan, R. A., 2011. New 40Ar/39Ar age progression for the Louisville hot spot trail and implications for inter-hot spot motion. Geochem. Geophys. Geosyst. 12, Q0AM02. https:// doi.org/10.1029/2011GC003804.

Koppers, A.A., Yamazaki, T., Geldmacher, J., Anderson, L., Beier, C., Buchs, D.M., Chen, L., Cohen, B., Deschamps, F., Dorais, M., Ebuna, D., Fitton, J., Fulton, P.M., Ganbat, E., Gee, J. S., Hamelin, C., Hanju, T., Hoshi, H., Kalnins, L., Kell, J., Machida, S., Mahoney, J.J., Moriya, K., Nichols, A.R.I., Pressling, N.J., Rausch, S., Sano, S., Sylvan, J.B., Williams, R., 2012a. Louisville Seamount Trail: implications for geodynamic mantle flow models 
and the geochemical evolution of primary hotspots. Proceedings of the IODP, Tokyo (Integrated Ocean Drilling Program Management International, Inc.). vol. 330.

Koppers, A.A.P., Yamazaki, T., Geldmacher, J., Gee, J.S., Pressling, N., Anderson, L., Beier, C., Buchs, D.M., Chen, L.H., Cohen, B.E., Deschamps, F., Dorais, M.J., Ebuna, D., Ehmann, S., Fitton, J.G., Fulton, P.M., Ganbat, E., Hamelin, C., Hanyu, T., Kalnins, L., Kell, J., Machida, S.,Mahoney, J.J.,Moriya, K., Nichols, A.R.L., Rausch, S., Sano, S., Sylvan, J.B.,Williams, R., 2012b. Limited latitudinal mantle plume motion for the Louisville hotspot. Nat.

Geosci. 5, 911-917.

Ling, H.F., Burton, K.W., O'Nions, R.K., Kamber, B.S., von Blanckenburg, F., Gibb, A.J., Hein, J. R., 1997. Evolution of $\mathrm{Nd}$ and $\mathrm{Pb}$ isotopes in Central Pacific seawater from ferromanganese crusts. Earth Planet. Sci. Lett. 146, 1-12.

Lonsdale, P., 1988. Geography and history of the Louisville Hotspot Chain in the southwest Pacific. J. Geophys. Res. Solid Earth 93, 3078-3104.

Lonsdale, P., Malfait, B., 1974. Abyssal dunes of foraminiferal sand on the Carnegie Ridge. Geol. Soc. Am. Bull. 85, 1697-1712.

Lonsdale, P., Normark,W.R., Newman,W.A., 1972. Sedimentation and erosion on horizon Guyot. Geol. Soc. Am. Bull. 83, 289-316.

Lyons, S.N., Sandwell, D.T., Smith, W.H.F., 2000. Three-dimensional estimation of elastic thickness under the Louisville ridge. J. Geophys. Res. Solid Earth 105, 13239-13252.

Marques, F.O., Hildenbrand, A., Zanon, V., Boulesteix, T., 2016. Comment on "the insular shelves of the Faial-Pico Ridge (Azores archipelago): a morphological record of its evolution" by Quartau et al. Geochem. Geophys. Geosyst. 17, 625-632.

Mattox, T.N., Mangan, M.T., 1997. Littoral hydrovolcanic explosions: a case study of lava-seawater interaction at Kilauea Volcano. J. Volcanol. Geotherm. Res. 75, 1-17.

Menard, H.W., 1984. Origin of Guyots: the beagle to seabeam. J. Geophys. Res. Solid Earth 89, 11117-11123.

Mitchell, N.C., Beier, C., Rosin, P.L., Quartau, R., Tempera, F., 2008. Lava penetrating water: submarine lava flows around the coasts of Pico Island, Azores. Geochem. Geophys. Geosyst. 9, Q03024. https://doi.org/10.1029/2007GC001725.

Moore, J.G., Phillips, R.L., Grigg, R.W., Peterson, D.W., Swanson, D.A., 1973. Flow of lava into the sea, 1969-1971, Kilauea Volcano, Hawaii. Geol. Soc. Am. Bull. 84, 537-546.

Moore, J.G., Clague, D.A., Holcomb, R.T., Lipman, P.W., Normark,W.R., Torresan, M.E., 1989. Prodigious submarine landslides on the Hawaiian ridge. J. Geophys. Res. Solid Earth 94, 17465-17484.

Mortimer, N., Hoernle, K., Hauff, F., Palin, J.M., Dunlap, W.J., Werner, R., Faure, K., 2006. New constraints on the age and evolution of the Wishbone Ridge, southwest Pacific Cretaceous microplates, and Zealandia-West Antarctica breakup. Geology 34, 185-188.

Murtagh, R.M., White, J.D.L., 2013. Pyroclast characteristics of a subaqueous to emergent Surtseyan eruption, Black Point volcano, California. J. Volcanol. Geotherm. Res. 267, 75-91.

Natland, J.H., 1976. Petrology of volcanic rocks dredged from seamounts in the Line Islands, Initial Reports of the Deep Sea Drilling Project. Texas A \& M University, Ocean Drilling Program, College Station, TX, United States, pp. 749-777.

Natland, J.H., Winterer, E.L., 2005. Fissure control on volcanic action in the Pacific. In: Foulger, G.R., Natland, J.H., Presnall, D.C., Anderson, D.L. (Eds.), Plates, Plumes and 
Paradigms, pp. 687-710.

Nayudu, Y.R., 1962. A new hypothesis for origin of Guyots and seamount terraces, in:

Macdonald, G.A., Kuno, H. (Eds.), the crust of the Pacific Basin. Am. Geophys. Union

171-180.

Nichols, A.R.L., Beier, C., Brandl, P.A., Buchs, D.M., Krumm, S.H., 2014. Geochemistry of volcanic glasses from the Louisville Seamount Trail (IODP Expedition 330): implications for eruption environments and mantle melting. Geochem. Geophys. Geosyst. 15, 1718-1738.

ODP Leg 197 Shipboard Scientific Party, 2002a. Site 1203. In: Tarduno, J.A., Duncan, R.A., Scholl, D.W., et al. (Eds.), Proc. ODP, Init. Repts., 197: College Station, TX (Ocean Drilling Program):pp. 1-171 https://doi.org/10.2973/odp. proc.ir.197.103.2002.

ODP Leg 197 Shipboard Scientific Party, 2002b. Site 1204. In: Tarduno, J.A., Duncan, R.A., Scholl, D.W., et al. (Eds.), Proc. ODP, Init. Repts., 197: College Station, TX (Ocean Drilling Program):pp. 1-125 https://doi.org/10.2973/ odp.proc.ir.197.104.2002.

ODP Leg 197 Shipboard Scientific Party, 2002c. Site 1205. In: Tarduno, J.A., Duncan, R.A., Scholl, D.W., et al. (Eds.), Proc. ODP, Init. Repts., 197: College Station, TX (Ocean Drilling Program):pp. 1-112 https://doi.org/10.2973/odp. proc.ir.197.105.2002.

ODP Leg 197 Shipboard Scientific Party, 2002d. Site 1206. In: Tarduno, J.A., Duncan, R.A., Scholl, D.W., et al. (Eds.), Proc. ODP, Init. Repts., 197: College Station, TX (Ocean Drilling Program):pp. 1-117 https://doi.org/10.2973/odp. proc.ir.197.106.2002.

Paduan, J.B., Clague, D.A., Davis, A.S., 2009. Evidence that three seamounts off southern California were ancient islands. Mar. Geol. 265, 146-156.

Pierson, T.C., 2005. Hyperconcentrated Flow - Transitional Process between Water Flow and Debris Flow, Debris-flow Hazards and Related Phenomena. Springer Berlin Heidelberg, Berlin, Heidelberg, pp. 159-202.

Portner, R., Clague, D., Paduan, J., 2014. Caldera formation and varied eruption styles on North Pacific seamounts: the clastic lithofacies record. Bull. Volcanol. 76, 1-28.

Powers,M.C., 1953. A new roundness scale for sedimentary particles. J. Sediment. Res. 23, 117-119.

Puteanus, D., Halbach, P., 1988. Correlation of Co concentration and growth rate a method for age determination of ferromanganese crusts. Chem. Geol. 69, 73-85.

Quartau, R., Tempera, F., Mitchell, N.C., Pinheiro, L.M., Duarte, H., Brito, P.O., Bates, C. R., Monteiro, J.H., 2012. Morphology of the Faial Island shelf (Azores): the interplay between volcanic, erosional, depositional, tectonic and mass-wasting processes. Geochem. Geophys. Geosyst. 13, Q04012. https://doi.org/10.1029/ 2011 GC003987.

Quartau, R., Hipólito, A., Romagnoli, C., Casalbore, D., Madeira, J., Tempera, F., Roque, C., Chiocci, F.L., 2014. The morphology of insular shelves as a key for understanding the geological evolution of volcanic islands: insights from Terceira Island (Azores). Geochem. Geophys. Geosyst. 15, 1801-1826.

Quartau, R.,Madeira, J.,Mitchell, N.C., Tempera, F., Silva, P.F., Brandão, F., 2015. The insular shelves of the Faial-Pico ridge (Azores archipelago): a morphological record of its evolution. Geochem. Geophys. Geosyst. 16, 1401-1420.

Quartau, R., Madeira, J., Mitchell, N.C., Tempera, F., Silva, P.F., Brandão, F., 2016. Reply to comment byMarques et al. on "the insular shelves of the Faial-Pico Ridge (Azores archipelago): a morphological record of its evolution". Geochem. Geophys. Geosyst. 17, 
633-641.

Ramalho, R.S., Quartau, R., Trenhaile, A.S., Mitchell, N.C.,Woodroffe, C.D., Ávila, S.P., 2013. Coastal evolution on volcanic oceanic islands: a complex interplay between volcanism, erosion, sedimentation, sea-level change and biogenic production. Earth Sci.

Rev. 127, 140-170.

Ramalho, R.S., Brum da Silveira, A., Fonseca, P.E., Madeira, J., Cosca, M., Cachão, M., Fonseca, M.M., Prada, S.N., 2015. The emergence of volcanic oceanic islands on a slow-moving plate: the example of Madeira Island, NE Atlantic. Geochem. Geophys. Geosyst. 16, 522-537.

Rhodes, J.M., Vollinger, M.J., 2004. Composition of basaltic lavas sampled by phase-2 of the Hawaii Scientific Drilling Project: geochemical stratigraphy and magma types.

Geochem. Geophys. Geosyst. 5, Q03G13.

Ryan, W.B.F., Carbotte, S.M., Coplan, J.O., O'Hara, S., Melkonian, A., Arko, R., Weissel, R.A., Ferrini, V., Goodwillie, A., Nitsche, F., Bonczkowski, J., Zemsky, R., 2009. Global multi-resolution topography synthesis. Geochem. Geophys. Geosyst. 10, Q03014. https://doi.org/10.1029/2008GC002332.

Salt, K.E., Ballantyne, C.K., 1997. The structure and sedimentology of relict talus, Knockan, Assynt, N.W. Scotland. Scott. Geogr. Mag. 113, 82-89.

Schipper, C.I., White, J.D.L., 2016. Magma-slurry interaction in Surtseyan eruptions. Geology 44, 195-198.

Schmidt, R., Schmincke, H.-U., 2000. Seamounts and island building. In: Sigurdsson, H., Houghton, B., McNutt, S.R., Rymer, H., Stix, J. (Eds.), Encyclopedia of Volcanoes. Academic Press, pp. 383-402.

Schmidt, R., Schmincke, H.-U., 2002. From seamount to oceanic island, Porto Santo, central East-Atlantic. Int. J. Earth Sci. 91, 594-614.

Seard, C., Camoin, G., Yokoyama, Y., Matsuzaki, H., Durand, N., Bard, E., Sepulcre, S., Deschamps, P., 2011. Microbialite development patterns in the last deglacial reefs from Tahiti (French Polynesia; IODP Expedition \#310): implications on reef framework architecture. Mar. Geol. 279, 63-86.

Sheppard, T.H., 2007. Life's a beach: lessons from the Earth's rarest sedimentary rocks. Geol. Today 23, 108-113.

Siebert, L., 1984. Large volcanic debris avalanches: characteristics of source areas, deposits, and associated eruptions. J. Volcanol. Geotherm. Res. 22, 163-197.

Simkin, T., 1972. Origin of some flat-topped volcanoes and guyots. Geol. Soc. Am. Mem. 132, 183-194.

Simpson, K., McPhie, J., 2001. Fluidal-clast breccia generated by submarine fire fountaining, Trooper Creek Formation, Queensland, Australia. J. Volcanol. Geotherm. Res. 109, 339-355.

Skilling, I.P., 2002. Basaltic pahoehoe lava-fed deltas: large-scale characteristics, clast generation, emplacement processes and environmental discrimination. Geol. Soc. Lond.,

Spec. Publ. 202, 91-113.

Skilling, I.P., White, J.D.L., McPhie, J., 2002. Peperite: a review of magma-sediment mingling. J. Volcanol. Geotherm. Res. 114, 1-17.

Smith, G.A., Lowe, D.R., 1991. Lahars: volcano-hydrologic events and deposition in the debris flow - hyperconcentrated flow continuum. In: Fisher, R.V., Smith, G.A.

(Eds.), Sedimentation in Volcanic Settings. SEPM Society for Sedimentary Geology, pp. 59-70.

Smoot, N.C., 1995. Mass-wasting and subaerial weathering in guyot formation - the Hawaiian and Canary Ridges as examples. Geomorphology 14, 29-41.

Staudigel, H., Clague, D.A., 2010. The geological history of deep-sea volcanoes. Oceanography $23,58-71$. 
Staudigel, H., Koppers, A.A.P., 2015. Seamounts and island building. In: Sigurdsson, H., Houghton, B., McNutt, S., Rymer, H., Stix, J. (Eds.), The Encyclopedia of Volcanoes,

2nd Edition Academic Press, pp. 405-422.

Staudigel, H., Schmincke, H.-U., 1984. The Pliocene seamount series of La Palma/Canary Islands. J. Geophys. Res. Solid Earth 89, 11195-11215.

Sun, S.Q., Wright, V.P., 1989. Peloidal fabrics in Upper Jurassic reefal limestones, Weald Basin, southern England. Sediment. Geol. 65, 165-181.

Tanner, L.H., Hubert, J.F., 1991. Basalt breccias and conglomerates in the Lower Jurassic McCoy Brook Formation, Fundy Basin, Nova Scotia; differentiation of talus and debrisflow deposits. J. Sediment. Res. 61, 15-27.

Thordarson, T., 2000. Physical volcanology of lava flows on Surtsey, Iceland: a preliminary report. Surtsey Res. 11, 109-126.

Tribble, G.W., 1991. Underwater observations of active lava flows from Kilauea volcano, Hawaii. Geology 19, 633-636.

Ui, T., 1983. Volcanic dry avalanche deposits - identification and comparison with nonvolcanic debris stream deposits. J. Volcanol. Geotherm. Res. 18, 135-150.

Vanderkluysen, L., Mahoney, J.J., Koppers, A.A.P., Beier, C., Regelous, M., Gee, J.S., Lonsdale, P.F., 2014. Louisville Seamount Chain: Petrogenetic processes and geochemical evolution of the mantle source. Geochem. Geophys. Geosyst. 15, 2380-2400.

Walton, A.W., Palmer, B.A., 1988. Lahar facies of the Mount Dutton Formation (OligoceneMiocene) in the Marysvale Volcanic Field, southwestern Utah. Geol. Soc. Am. Bull. 100, 1078-1091.

Watton, T.J., Jerram, D.A., Thordarson, T., Davies, R.J., 2013. Three-dimensional lithofacies variations in hyaloclastite deposits. J. Volcanol. Geotherm. Res. 250, 19-33.

White, J.D.L., Houghton, B.F., 2006. Primary volcaniclastic rocks. Geology 34, 677-680. 